
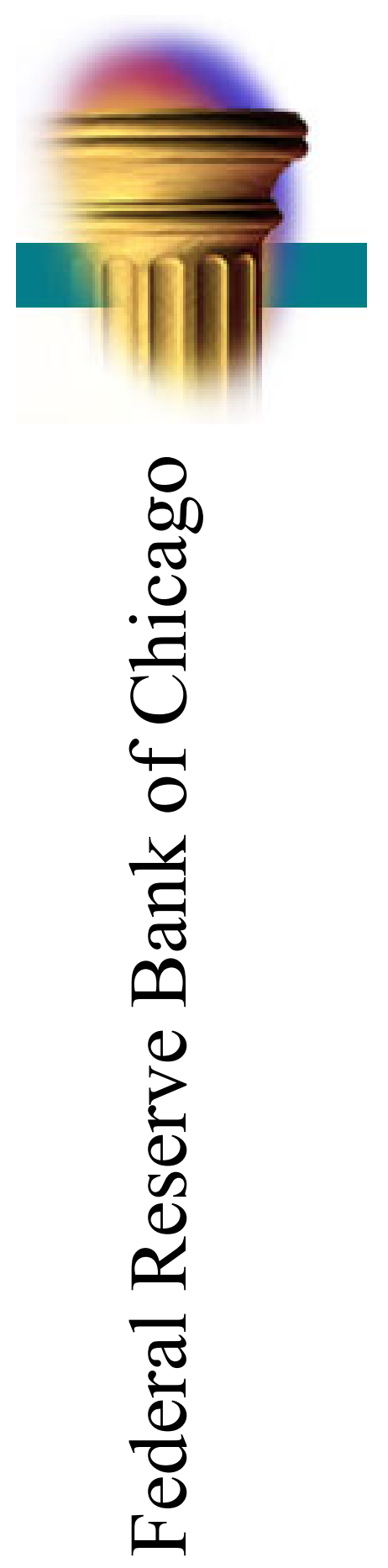

\title{
Lottery Loans in the Eighteenth Century
}

François R. Velde

\section{May 12, 2018}

\section{WP 2018-07}

\author{
https://doi.org/10.21033/wp-2018-07
}

${ }^{*}$ Working papers are not edited, and all opinions and errors are the responsibility of the author(s). The views expressed do not necessarily reflect the views of the Federal Reserve Bank of Chicago or the Federal Reserve System. 


\title{
Lottery Loans in the Eighteenth Century
}

\author{
François R. Velde* \\ Federal Reserve Bank of Chicago
}

May 12, 2018

\begin{abstract}
In the 18th century Britain frequently issued lottery loans, selling bonds whose size was determined by a draw soon after the sale. The probability distribution was perfectly known ex-ante and highly skewed. After the draw the bonds were identical (except for size) and indistinguishable from regular bonds. I collect market prices for the lottery tickets and show that investors were paying a substantial premium to be exposed to this purely artificial risk. I show that investors were well-to-do and included many merchants and bankers. I turn to cumulative prospect theory to make sense of these observations and estimate the equilibrium model of Barberis and Huang (2008). The preference parameters can account for the level of the lottery premium but cannot always match the systematic rise of prices over the course of the draws.
\end{abstract}

Keywords: lotteries, behavioral finance, cumulative prospect theory, Great Britain, government debt (JEL D81, G12, N13).

*I thank Keyoung Lee and Anu Aekka for their help in developing the Matlab code, and Ross Gehm for his help in identifying the 1711-12 winners. Participants at several workshops offered valuable feedback. The opinions expressed are not necessarily those of the Federal Reserve Bank of Chicago or the Federal Reserve System. 


\section{Introduction}

Preferences are a basic building block of economic models and, among other things, represent attitudes toward risk. The expected-utility framework has been used for decades and questioned for almost as long (Allais 1953). Economists are increasingly exploring alternative frameworks, both theoretically and empirically, but clean tests are difficult to come by. Experiments and surveys (Abdellaoui, Bleichrodt, and L'Haridon 2008; Roger 2011) rely on hypothetical situations or involve small stakes. Studies of asset prices (Green and Hwang 2012; Eraker and Ready 2013; Conrad, Dittmar, and Ghysels 2013; Boyer and Vorkink 2014) have to make assumptions about investors' knowledge of the distributions of returns. Gambling and betting (Garrett and Sobel 1999; Golec and Tamarkin 1998) might be merely recreational. Testing these theories would be more convincing if we had observations on an important financial market, populated with serious investors trading government bonds and equity alongside highly skewed securities, with perfectly known and sufficiently varied returns. That's what this paper is about.

In the eighteenth century Britain (among other nations) repeatedly issued lottery loans as part of war financing. The loans all had the following characteristics. Investors paid a known sum and received in exchange a ticket in a lottery whose prizes were standard bonds, but of different sizes. Put another way, investors exchanged a price $p$ for a stream of payments $\left\{\alpha r_{1}, \alpha r_{2}, \alpha r_{3} \ldots\right\}$ where $\alpha$ was a highly skewed random variable determined by a lottery soon after purchase. After the draw the bonds were identical, except for size, and riskless. The probability distribution was perfectly known. Thirty-seven lottery loans were issued between 1694 and 1776; in addition, for each lottery loan the draw of the lottery took several weeks. Before and during the draw, undrawn tickets traded on the secondary market, alongside non-randomized versions of the underlying bond. Contemporary newspapers reported prices, and also which prizes were drawn each day, so that the distribution of remaining prizes can be reconstructed. The resulting data-set consists of several hundred pairs of lotteries and market prices, and the latter are almost always higher than the risk-neutral or actuarially fair price.

One might wonder who were the participants in these markets. I document that the lottery tickets were very expensive and that investors who held those lottery tickets belonged to the upper portion of the income distribution: prosperous and successful individuals, often with financial and other wealth (therefore not credit-constrained individuals as in Crossley, Low, and Smith 2011). One might also wonder about the nature and depth of these markets. I provide qualitative evidence that they were well informed, active, and sophisticated: not only were lottery tickets traded, but also derivatives on these tickets, such as forwards, options, and repos.

Market prices consistently show a sizeable premium for the lottery tickets over the nonrandom bond. This negative excess return easily explains the supply of lottery loans, but an expected utility framework with risk aversion will not account for the demand. There 
are a number of alternative theories (e.g., Brunnermeier and Parker 2005 or Roussanov 2010). I turn to Cumulative Prospect Theory (CPT) which has been increasingly used recently to understand the relation between skewness and low returns in equity and other markets (see the survey in Barberis 2013). Specifically, the model of Barberis and Huang (2008), has the advantage of pricing a standard normal asset alongside the lottery, and, as an equilibrium model, making predictions about demand for the lottery. The model is parsimonious: three parameters characterize preferences and the extent of probability distortion.

I estimate these parameters on the British eighteenth century data. I find that this model of homogeneous investors with CPT preferences can rationalize the equity premium on equity and the negative excess returns on the lotteries. The parameter estimates are in line with the experimental evidence of Tversky and Kahneman (1992) and well within the broad range of survey-based estimates (Rieger, Wang, and Hens 2017). The model, however, does not always reproduce the rather systematic rise in the price of the lottery tickets over the course of the draw. Contemporary evidence suggests that the tickets were the object of intense speculation as the draw took place.

The rest of the paper is simply organized: section 2 presents the historical context, describes the lotteries and the markets in which the tickets and various derivatives were trades. Section 3 presents the data and the estimation method and results.

\title{
2 Lottery Loans in English and British public finance
}

\author{
A Lottery is a taxation \\ Upon all the fools in creation; \\ And Heav'n be prais'd \\ It is easily rais'd. . . \\ The Lottery (1731) \\ Henry Fielding
}

Randomizing devices have long been used for convexification purposes (Bronze Age examples include Numbers 26:55 and Iliad 7:175). Selling lotteries for more than their expected value is an old method of raising revenues; in Europe the earliest attested examples appear in the Low Countries in the mid-15th century, when cities organized lotteries to finance capital improvements and charitable works (Bernard et al. 1994). The use of lotteries spread to Italy in the 16th century. In Genoa the lottery evolved from popular betting on the selection of senators, which had been entrusted to chance in order to avoid political interferences (Bellhouse 1991; Assereto 2013). Private and public lotteries were organized in Rome and Venice, which may have been the first government to issue public debt through lotteries (Welch 2008; Bellhouse 1991).

Private and public lotteries developed throughout Europe in the 16th and 17th centuries (Huisman and Koppenol 1991; Thijs 1994), the latter increasingly driving out the former by legislative means in the 18th century. Lottery loans, that is, holding lotteries whose prizes were government bonds, make their definitive appearance toward the end 
of the 17th century. The first lottery loan of 1694 in England was followed by Dutch lottery loans in 1709 (Hoekstra 2010). Britain and the Netherlands continued their issues through the eighteenth century, and imitating each other and imitated by others such as France (Kruckeberg 2009; Pfiffelmann 2012) and various German states. The use of lottery loans continued well into the 19th century (e.g., the Russian bonds studied by Ukhov 2010) but moral and legal concerns grew. Privately issued lottery bonds were prohibited and states increasingly turned away from their use (Lévy-Ullmann 1896). After World War I moral concerns abated before necessity and lottery bonds returned in Belgium (Gilson, Oosterlinck, and Ukhov 2013), the Soviet Union (Millar and Gentry 1980) Sweden (Green and Rydqvist 1997), Denmark (Florentsen and Rydqvist 2002), the United Kingdom (Tufano 2008; Lobe and Hölzl 2007), and New Zealand (Ridge and Young 1998). Private issues of lottery bonds also exist (Guillén and Tschoegl 2002).

Modern lottery bonds typically present randomized coupon payments and thus carry risk throughout their lifespan, whereas the early lottery loans lost all randomness within a few weeks of their floatation and before the first coupon payment. This makes their design and pricing particularly simple. I focus on the British loans because of the availability of market prices for the tickets.

\subsection{Overview}

The first major lottery loan took place in England in 1694, in the midst of war. ${ }^{1}$ Called the Million Lottery, it had many features of its successors (Murphy 2005). Tickets were sold for $£ 10$ each and all entitled the bearer to an annuity of $£ 1$ per year for 16 years, payable twice a year. Furthermore 2,500 tickets would receive an additional 16-year annuity, ranging from $£ 10$ to $£ 1000$. Of these additional prizes, one $£ 100$ annuity went to the first-drawn ticket, and one $£ 150$ annuity to the last-drawn ticket. The subscription opened immediately on March 26 , and it filled steadily: $£ 400,000$ by mid-April, $£ 832,000$ by mid-May and by late June it was closed. The drawing started on October 8 and took two months. Two boxes were displayed, one containing all the ticket numbers and the other containing slips for all the prizes, and blank slips for the rest.

A second lottery loan (called the "Malt lottery" because it was funded with duties on malt) was issued soon after, in 1697. It failed because the terms were not generous: only $1 \%$ of the tickets were sold, the rest was used by the Exchequer as a form of cash (Gallais-Hammono and Rietsch 2013).

Perhaps spurred by the example her Dutch ally, Britain resumed lottery loans in 1710, returning to the model of the successful Million Lottery of 1694, and kept them as a regular feature of public finance for decades. ${ }^{2}$ They continued until 1776, by which time a total

\footnotetext{
${ }^{1}$ See Ewen (1932) for an excellent general history of British lotteries (earlier and less exhaustive treatments include Walford 1885 and Ashton 1893), United Kingdom (1898), Richards (1934), and Cohen (1953), and Dickson (1967) for their place in British public finance.

${ }^{2}$ The Estates General issued lottery loans from 1709 and Holland from 1711. The first Dutch loans of 1709 offered prizes in the form of life annuities, and those of 1710-13 offered 20-year annuities, perhaps imitating the British 1710 lottery. Conversely the Holland loans of 1711-13, which offered interest-bearing bonds repaid over the course of 30 years, may have influenced the British loans of 1711-14. See Fokker 1862; Hoekstra 2010 and the the loan descriptions in the Gazette d'Amsterdam.
} 


\begin{tabular}{lrrr}
\hline \multirow{2}{*}{ Period } & \multicolumn{2}{c}{ Increases in funded debt $(£)$} & \\
\cline { 2 - 3 } & \multicolumn{1}{c}{ Total } & Lottery loans & $(\%)$ \\
\hline $1694-1700$ & $8,380,230$ & $1,000,000$ & 11.9 \\
$1703-15$ & $37,448,102$ & $10,500,000$ & 28.0 \\
$1719-26$ & $19,429,220$ & $4,911,990$ & 25.3 \\
$1742-51$ & $31,489,272$ & $4,672,727$ & 14.8 \\
$1755-68$ & $64,095,553$ & $6,042,256$ & 9.4 \\
\hline
\end{tabular}

Table 1: Increases in the funded debt, total and through lottery loans. Source: United Kingdom $(1898,5-6,14-29)$.

of 37 lottery loans had been issued. ${ }^{3}$ Lottery loans were issued during periods of debt refinancing (1719-26) or during wars and in their immediate aftermath (1710-14, 1743-51, 1755-68, 1776). Table 1 shows that they represented a substantial although declining share of gross debt issues. In February 1769, as the government was working on the budget, rumors of a new lottery loan circulated, but ultimately it was decided to launch a pure cash lottery instead, that is, one which paid cash prizes rather than bonds. The Prime Minister, Lord North, was reported (Cobbett 1806-1820, 16:608) as declaring in his budget speech that:

"... a lottery being a tax on the willing only, though many might object to it, as an encouragement of gaming, yet he thought the public would be right to avail themselves of the folly of mankind, especially as it laid no burthen on the poor; that lotteries were of various natures, and the more they were varied, the more desirous the public were of running into them: he thought it good policy not to over-stretch them, as that would be destroying the hen for her eggs."

Except in 1776, when a last lottery loan was issued, the cash lottery became the norm, either stand-alone (in 1769 and 1771), or in conjunction with annuity conversions (1770, $1772,1774-75)$ or new annuities (1777 to 1784). In the latter case the lottery tickets were offered to annuity subscribers at favorable prices. Then, from 1785 the "State Lottery" was a simple cash lottery open to all, held once a year (until 1801) or more. ${ }^{4}$ The government's share varied between 20 and 50\%. Ultimately, concerns about the morality of the lottery and its incidence on the poor led to its abolition in 1826.

\subsection{Characteristics}

With the exception of the "class lotteries" of 1711 and 1712 (described below), the lotteries all shared the same characteristics. Tables 2 and 3 presents the general characteristics of the loans and Tables 4 and 5 shows the probabilities of the prizes and blanks. The characteristics of the loans, including the distribution of pay-offs, all come from the acts passed by Parliament.

\footnotetext{
${ }^{3}$ I exclude the guinea lottery of 1757 , a cash lottery that fared poorly, as well as a few other special-purpose lotteries such as the Westminster Bridge lotteries of 1737-42 (with $£ 5$ tickets) and the British Museum lottery of 1753 (with $£ 3$ tickets).

${ }^{4}$ Between 1815 and 1821 prizes in several lotteries were paid in a mixture of cash and consols.
} 


\section{Issue}

The ticket price was usually $£ 10$ (except for the "classes" lotteries of 1711 and 1712 , at $£ 100$, and the lotteries of 1719 and 1760, at $£ 3$ ). The tickets were sold for cash, except in 1748 and from 1759 to 1768 when the tickets bundled with new issues of perpetual annuities; but even in those cases, the tickets were issued as a separate, tradeable security to the bearer with a face value of $£ 10$ (the number of tickets given for each $£ 100$ in annuities varied by loan). The tickets could often be bought in installments, sometimes with a discount for early payment. ${ }^{5}$ The draw took place within a few months of the subscription, always in the great medieval hall of Guildhall in London and always following the same format (Figure 1). Two six-foot wooden wheels were filled, one with the ticket numbers, the other with the prizes and blanks (see Figure 1). One paper was drawn from each by a "blue coat" (a student at a charity school in London) and the match recorded by the clerks under the watchful eye of the commissioners. The draws took place six days a week, from 9 in the morning to 3 in the afternoon, except holidays.

Most of the issues were successful, subscriptions being filled within a month, sometimes within a few days (Daily Journal, issue 636). From the 1740s the subscription were opened at the Bank of England on the basis of a resolution of the House of Commons, before the loan act had received the royal assent. In 1722, it was reported that brokers charged a 5s premium to deliver the tickets (Daily Journal, 2 Mar 1722, n346). A few issues, made shortly after the South Sea Bubble, were not successful: when the draw of the 1721 lottery began it was reported that $39 \%$ of the tickets were held by the government (Evening Post, issue 1901). Likewise, the 1726 lottery was quoted at a discount on the secondary market throughout the subscription, and when the draw began it was reported in the papers that $11 \%$ of the tickets remained in the Exchequer (Daily Journal, 20 Sep 1726, issue 1773).

\section{Prizes}

What the draw determined was the size of the bond to which the bearer was entitled. The 1719 lottery was peculiar in offering a cheaper ticket (£3) and in giving no prizes to the blanks, no doubt because of the costs of paying annuities as small as $£ 0.12$. In all other lotteries, each ticket received a long-term government bond of some size. The nature of the bond changed over time. The first lotteries, in 1694 and 1710, offered 16-year annuities with no repayment of principal; the prizes were expressed in terms of the annuity, and are capitalized at 10 to make them comparable in Tables 4 and 5.

From 1711 to 1719 the lotteries offered bonds with a fixed coupon and repayment of principal over a period of 32 years. The order in which the bonds were repaid was determined by a second draw. The acts appropriated the revenues from certain taxes to the payment of interest and principal, but if funds were insufficient the repayment was merely delayed, with interest accruing at the statutory rate. The lotteries of 1721-24 formally promised repayment within a year of the draw, with interest to accrue at a set rate

\footnotetext{
${ }^{5}$ In 1712 and 1743 , the last payment was due after the draw.
} 


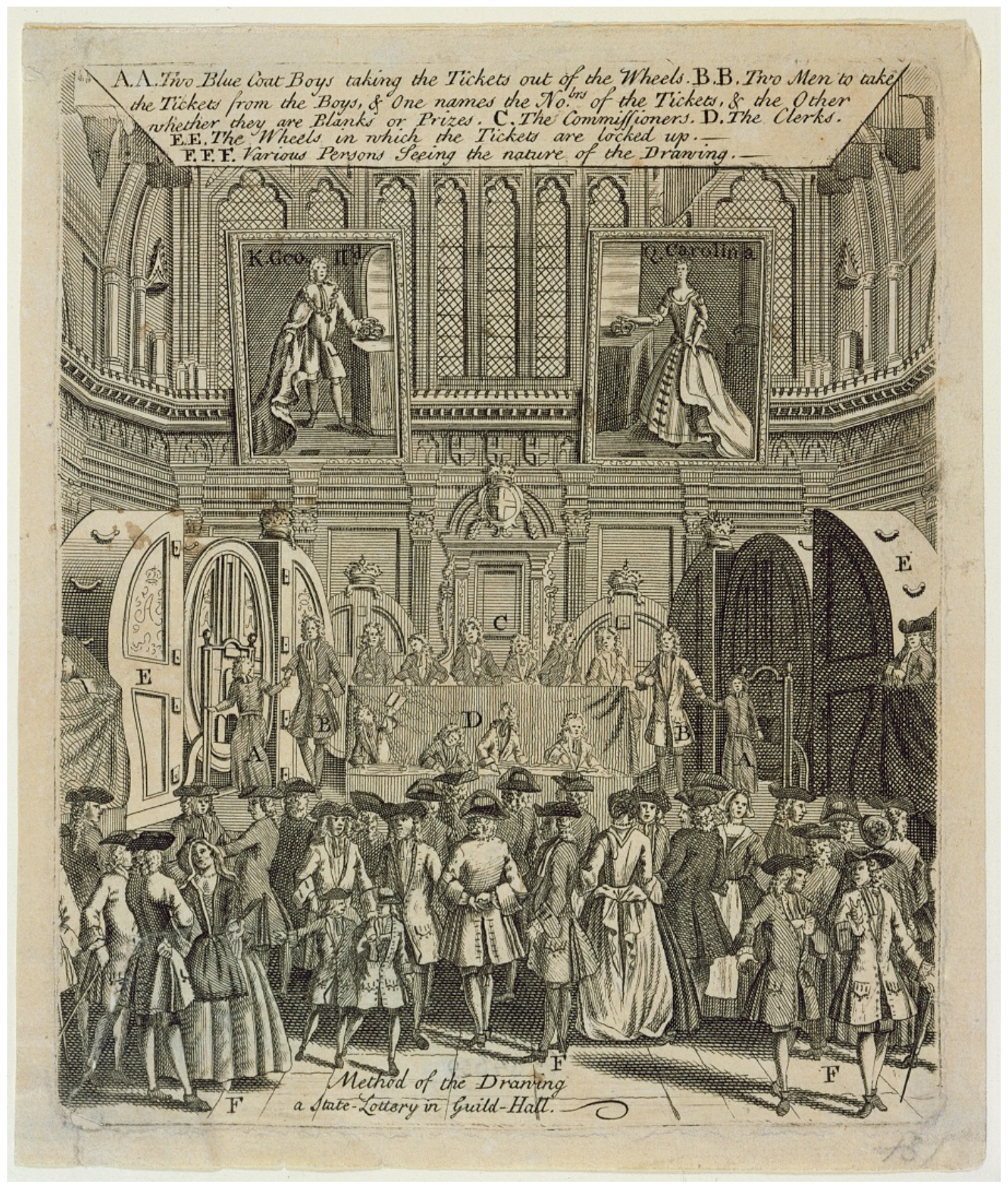

Figure 1: The randomizing device: method of the drawing a State Lottery at Guildhall, 1739 (engraving) by Guildhall Library, City of London/ The Bridgeman Art Library. 


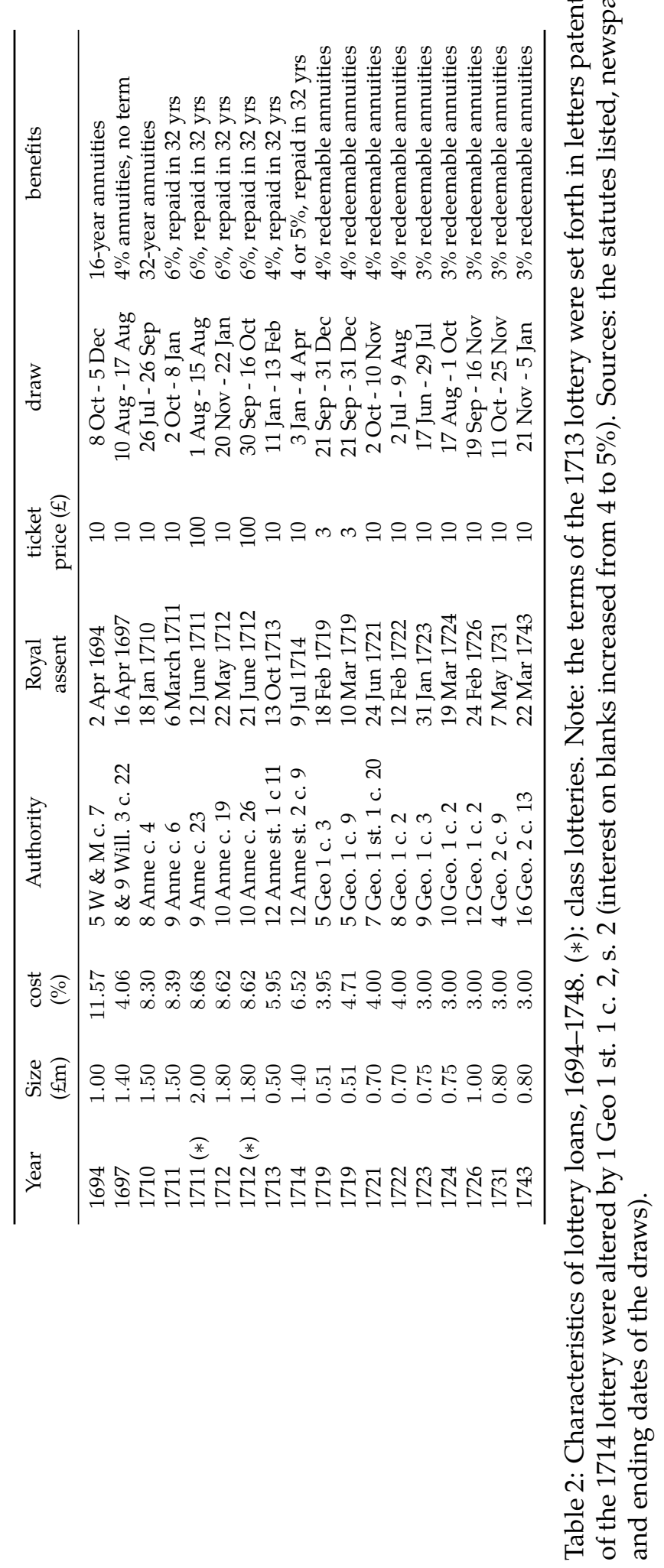




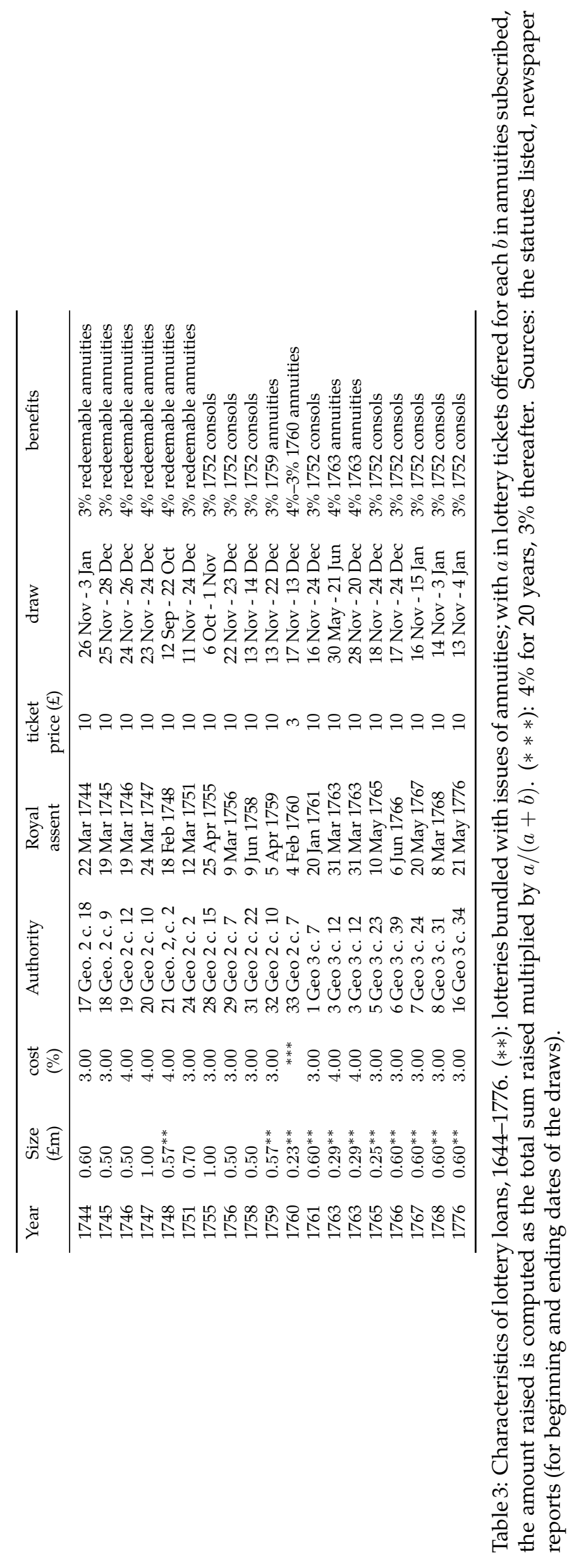




\begin{tabular}{|c|c|c|c|c|c|c|c|c|c|}
\hline & 1694 & 1710 & 1711 & $\begin{array}{c}1711 \\
\text { (classes) }\end{array}$ & 1712 & $\begin{array}{c}1712 \\
\text { (classes) }\end{array}$ & 1713 & 1714 & 1719 \\
\hline 20,000 & & & & 5.0 & & 5.6 & & 0.7 & 0.6 \\
\hline 12,000 & & & 0.7 & & 1.7 & & & & \\
\hline 10,000 & 1.0 & 0.7 & & & & & 4.0 & 1.4 & 1.2 \\
\hline 5,000 & 9.0 & 2.0 & 2.0 & 10.0 & 1.7 & 11.1 & 2.0 & 2.1 & 3.0 \\
\hline 4,000 & & 2.7 & 2.7 & 15.0 & 1.7 & 16.7 & 2.0 & 2.9 & \\
\hline 3,000 & & 2.7 & 2.7 & 20.0 & 3.3 & 22.2 & 2.0 & 3.6 & \\
\hline 2,000 & & 2.7 & 2.7 & 20.0 & 3.3 & 22.2 & 2.0 & 7.1 & \\
\hline 1,500 & 1.0 & & & & & & & & \\
\hline 1,000 & 21.0 & 13.3 & 13.3 & 25.0 & 16.7 & 27.8 & 10.0 & 15.0 & 17.8 \\
\hline 500 & 80.0 & 21.3 & 21.3 & 70.0 & 33.3 & 22.2 & 20.0 & 29.3 & 42.1 \\
\hline 400 & & & & 80.0 & & 88.9 & & & \\
\hline 300 & & & & 100.0 & & 111.1 & & & \\
\hline 250 & 90.0 & & & & & & & & \\
\hline 200 & 300.0 & 66.7 & 66.7 & 3750.0 & 50.0 & 9405.6 & 40.0 & 71.4 & \\
\hline 105 & & & & & & & & & \\
\hline to 130 & & & & 99655.0 & & 90266.7 & & & \\
\hline 100 & 2000.0 & 400.7 & 166.7 & & 166.7 & & 100.0 & 357.1 & 239.5 \\
\hline 50 & & 1988.7 & 954.0 & & 940.0 & & 800.0 & 714.3 & 474.3 \\
\hline 25 & & & & & & & & & 834.8 \\
\hline 20 & & & 15434.0 & & 15448.3 & & 12982.0 & 16126.4 & \\
\hline 10 & 97500.0 & & 83333.3 & & 83333.3 & & 86036.0 & 82668.6 & 15053.5 \\
\hline 8 & & & & & & & & & \\
\hline 7 & & 97500.0 & & & & & & & \\
\hline 0 & & & & & & & & & 83333.2 \\
\hline
\end{tabular}

Table 4: Probabilities of the prizes (1694-1719). The total number of tickets is normalized to 100,000 . Note: For the 1694 and 1710 lotteries, the annuities are capitalized at 10 years to make them comparable to the other lotteries. Sources: the statutes listed in Tables 2 and 3 .

\begin{tabular}{rrrrrrrrrr}
\hline & $1721-2$ & $1723-4$ & \multicolumn{1}{c}{1726} & 1731 & 1743 & 1744 & $1745-7$ & 1748 & 1751 \\
\hline 20,000 & & & 1.0 & & & & & & \\
10,000 & 1.4 & 1.3 & 2.0 & 2.5 & 2.5 & 3.3 & 4.0 & 4.8 & 2.9 \\
5,000 & 2.9 & 2.7 & 2.0 & 5.0 & 5.0 & 6.7 & 6.0 & 6.3 & 5.7 \\
3,000 & 2.9 & 2.7 & 3.0 & 2.5 & 2.5 & & & & 7.1 \\
2,000 & 4.3 & 4.0 & 5.0 & 6.3 & 6.3 & 8.3 & 10.0 & 11.1 & 11.4 \\
1,000 & 30.0 & 28.0 & 29.0 & 18.8 & 20.0 & 21.7 & 32.0 & 31.7 & 30.0 \\
500 & 44.3 & 54.7 & 50.0 & 27.5 & 32.5 & 43.3 & 64.0 & 63.5 & 60.0 \\
100 & 214.3 & 333.3 & 360.0 & 296.3 & 311.3 & 331.7 & 302.0 & 271.4 & 285.7 \\
50 & 571.4 & 666.7 & & & 586.3 & 673.3 & 796.0 & 701.6 & 600.0 \\
20 & 9128.6 & 8906.7 & 7550.0 & 9643.8 & 10773.8 & 15215.0 & 13090.0 & 12801.6 & 13285.7 \\
8 & 90000.0 & & & & & & & & \\
7.5 & & 90000.0 & 91998.0 & 89997.5 & & & & & \\
7 & & & & & 88260.0 & & & & \\
6 & & & & & & 83696.7 & 85696.0 & 86107.9 & 85711.4 \\
\hline
\end{tabular}

Table 5: Probabilities of the prizes (1721-51). The total number of tickets is normalized to 100,000. Sources: the statutes listed in Tables 2 and 3.

on all unredeemed tickets until repayment was effected. This was a perpetual redeemable annuity in all but name, and all subsequent lotteries from 1726 explicitly offered fixed-rate annuities with no set repayment date but redeemable upon six months' notice. After the consolidation of the public debt in 1750, a number of lotteries paid out in 3\% consolidated annuities. From 1722 the annuities were paid at the Bank of England like most of the public debt. ${ }^{6}$

The so-called "class lotteries" of 1711 and 1712 were a little different: not only was

\footnotetext{
${ }^{6}$ For some of the lottery loans of the 1750s and 1760s, which were bundled with other issues of annuities, the lottery's annuities began accruing six or twelve months later than the regular annuities with which they were bundled.
} 


\begin{tabular}{|c|c|c|c|c|c|c|c|c|c|}
\hline & 1755 & $\begin{array}{l}1756 \\
1758\end{array}$ & 1759 & 1760 & $\begin{array}{l}1761 \\
1765 \\
1766\end{array}$ & 1763 & 1767 & 1768 & 1776 \\
\hline 20,000 & & & 3.0 & & & & 1.7 & 3.3 & 3.3 \\
\hline 10,000 & 2.0 & 4.0 & & 2.5 & 3.3 & 5.7 & 5.0 & 6.7 & 5.0 \\
\hline 5,000 & 4.0 & 6.0 & 3.0 & 2.5 & 3.3 & 5.7 & 6.7 & 8.3 & 8.3 \\
\hline 3,000 & & & 3.0 & & & & & & \\
\hline 2,000 & 6.0 & 12.0 & 3.0 & 5.0 & 6.7 & 11.4 & 16.7 & 16.7 & 20.0 \\
\hline 1,000 & 32.0 & 36.0 & 39.4 & 17.5 & 18.3 & 31.4 & 31.7 & 35.0 & 40.0 \\
\hline 500 & 42.0 & 60.0 & 47.0 & 27.5 & 35.0 & 80.0 & 71.7 & 68.3 & 83.3 \\
\hline 100 & 198.0 & 284.0 & 227.3 & 125.0 & 166.7 & 357.1 & 333.3 & 333.3 & 333.3 \\
\hline 50 & 4020.0 & 1252.0 & 1060.6 & 500.0 & 335.0 & 1514.3 & 1016.7 & 1000.0 & 1000.0 \\
\hline 20 & & 11350.0 & 12768.2 & 2500.0 & 19343.3 & 14571.4 & 34916.7 & 31958.3 & 31833.3 \\
\hline 6 & 95696.0 & 86996.0 & 85845.5 & & 80088.3 & & & & \\
\hline 5 & & & & & & 83422.9 & & & \\
\hline 0 & & & & 83445.0 & & & 63600.0 & 66570.0 & 66673.3 \\
\hline
\end{tabular}

Table 6: Probabilities of the prizes (1755-76). The total number of tickets is normalized to 100,000. Sources: the statutes listed in Tables 2 and 3.

their price higher ( $£ 100$ instead of $£ 10$ ), but the prizes were grouped in five classes; the order of reimbursement was determined by the class, and the capital of the blanks in each class was larger for the later classes, ranging from $£ 110$ to 130 for the 1711 class lottery, and from $£ 105$ to $£ 125$ for the 1712 class lottery. The repayment was scheduled to be completed within 32 years as with the other lotteries of the 1711-19 period.

The repayment history of the early lottery loans is not stellar. The 1694 lottery ran into arrears almost immediately; funds were appropriated in 1698 and the original payment schedule was restored. Payments on the annuities of the 1710 lottery fell immediately one year behind and remained for several years, as did the interest payments and reimbursements on the 1711 and 1712 lotteries, which were five quarters behind by 1717. Most of the 1710 annuities and the capital owed on the lotteries of 1711-14 were converted into South Sea Stock in two operations, in 1717 and 1720, eventually becoming 5\% perpetual annuities (United Kingdom 1898). What was not converted was paid off progressively during the 1720s. After the South Sea conversions, the British debt was put on a sound footing and the lottery loans, like the rest of the debt, was punctually served and became quite safe. The lotteries of 1721-24 were each paid off within two years. From 1726 to 1768 the lottery loans were almost all of the same type: $£ 10$ tickets, prizes up to $£ 10,000$ ( $£ 20,000$ in a few instances) in the form of standard perpetual redeemable annuities (now known as "consols" after the consolidation of 1751).

\subsection{Who invested in the lotteries?}

If we are to use data concerning these lottery loans to make inferences about investor preferences and attitudes toward risk, it is useful to have a sense of who, in fact, held these lottery tickets.

There are roughly two approaches, each based on different sources. The first relies on contemporary news reports, and the fact that winners of big prizes are, by construction, a random sample of investors. The second relies on archival material: although lottery tickets were bearer instruments, the bonds received as prizes were not, and in some instances 
it is possible to find listing of the bond owners.

\begin{tabular}{lrc}
\hline & \multicolumn{2}{c}{ Families } \\
& number & income $(£)$ \\
\hline Temporal lords & 200 & 6060 \\
Baronets & 800 & 1500 \\
Spiritual lords & 26 & 1300 \\
Knights & 600 & 800 \\
Esquires & 3,000 & 562.5 \\
Greater merchants & 5,264 & 400 \\
Gentlemen & 15,000 & 280 \\
Persons in offices, greater & 5,000 & 240 \\
Lesser merchants, artisans and handicrafts & 27,802 & 200 \\
Persons in the Law & 8,062 & 154 \\
Persons in offices, lesser & 5,000 & 120 \\
Freeholders, greater & 27,568 & 91 \\
Naval officers & 5,000 & 80 \\
Clergymen, greater & 2,000 & 72 \\
Persons in sciences and liberal arts, military officers & 16,898 & 60 \\
Freeholders, lesser & 96,490 & 55 \\
Clergymen, lesser & 10,000 & 50 \\
Shopkeepers and tradesmen & 101,704 & 45 \\
Farmers & 103,382 & 42.5 \\
Manufacturing trades & 162,863 & 38 \\
Building trades & 73,018 & 25 \\
Common seamen & 50,000 & 20 \\
Laboring people and outservants, miners & 299,237 & 15 \\
Common soldiers & 35,000 & 14 \\
Cottagers and paupers & 313,183 & 6.5 \\
vagrants & 23,489 & 2 \\
\hline All Families & $1,390,586$ & 39.1 \\
\hline
\end{tabular}

Table 7: Social Table of England and Wales, 1688. Source: Lindert and Williamson (1982, Table 2).

\section{Winners}

Then as now big lottery prizes were newsworthy. Tables 8, 9, and 10 report the names and occupations of the winners reported in contemporary newspapers which, as can be seen, were nearly comprehensive. The reports become more detailed over time, and are particularly abundant for the 1719 lottery (Table 9).

There are no apparent reasons to doubt the accuracy of the reports. In many instances it is possible to find additional information about the named winners, and even independent corroboration of the prize.

The winners of the big prize in 1694 were two French Huguenots who left France after the repeal of the edict of tolerance in 1685: Samuel Ravenel, seigneur du Boistilleul (c1676-1731) a nobleman from Brittany living with the duke of Leeds, and François Le Cocq (1640-1719), a magistrate in the Parlement of Paris (Douen 1894, 2:373-78, Lart 1924, 1:90).The winner of the top prize in the 1712 classes lottery, Thomas Weddell, was a merchant from York; cousin of the chancellor of the Exchequer John Aislabie, he was paymaster of the Navy and enriched himself during the South Sea bubble; he won several other prizes in the same lottery and left $£ 70,000$ at his death. Samuel Strode, a barber-surgeon, who shared $£ 5,000$ in the same lottery, bought Ponsbourne mansion in Hertfordshire in 1718 for $£ 6,800$; his son William was MP for Reading. Matthew Wymondesold, the other 


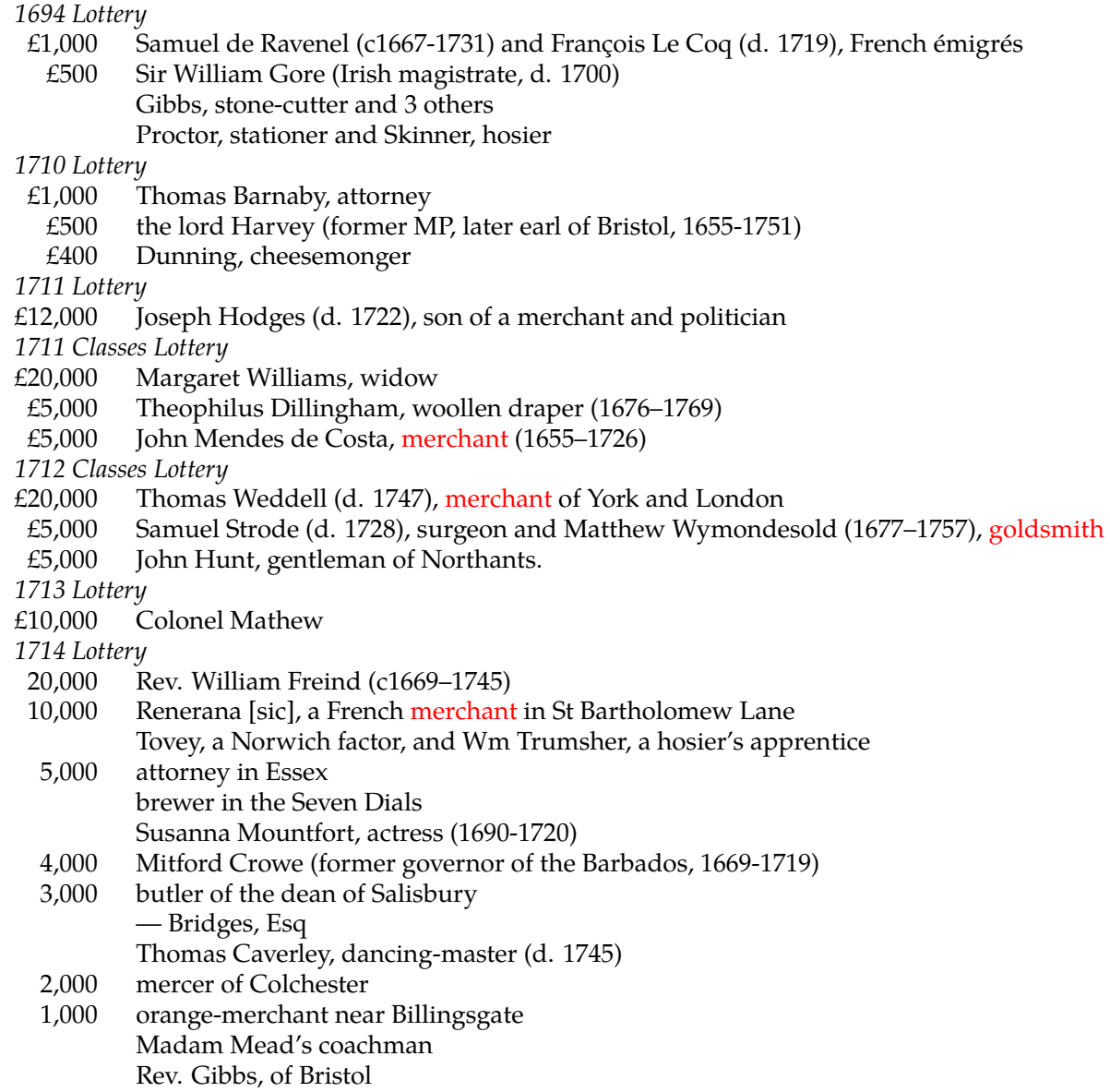

Table 8: Some winners of the largest prizes, 1694-1714. Sources: Gazette d'Amsterdam 1 Nov 1694 issue 87, 15 Nov 1694 issue 91, Luttrell 1857, 3:380-394, 6:611-618, Protestant Post-Boy 5 Jan 1712, (Ewen 1932, 137, 140), Post Boy issue 2925, Weekly Journal, Jan 29 Jan, 12, 19 Feb, 12, 26 Mar 1715, Weekly Packet issue 137.

claimant of the prize, was John Aislabie's broker. Joseph Hodges, who won in 1711, was the son of Sir William Hodges (c1645-1714), a merchant, director of the Bank of England, and MP.

The winners of the first 1719 lottery were two German Jews, whose generosity after their good fortune was prominently featured in London newspapers: they were Moses Hart (1675-1756), a merchant who was employed in financial dealings for the government of Queen Anne, and Isaac Franks, a stockbroker who soon after married one of Hart's daughters and received the half of the ticket he did not own as part of the marriage contract. Remarkably, Isaac Franks had previously won 30,000 florins (the equivalent of $£ 2750$ ) in a Dutch lottery in 1715 (Weekly Journal, 1 Jan 1715). John Rudge, who won $£ 10,000$ in the same lottery, was a prominent merchant and director of the Bank of England, having served as its governor in 1713-14. Another winner was Robert Heysham, a merchant, banker, shipowner and broker, and MP for London. George Wanley, a goldsmith and banker (whose partnership eventually became Goslings and Sharpe), retired in 1720 to his house in Tottenham where he died in 1729; his daughter and heiress married in 1728 the son of a former director of the South Sea Company, and was said to be worth $£ 30,000$ 
1719 Lottery

20,000 Moses Hart (1675-1756) and Isaac Franks (d. 1736), merchants

Mr Cox, a merchant in Berry-St

10,000 a poor clothier in Newberry with ten children

John Rudge (1669-1740), merchant, MP, director of the Bank

5,000 Mr Warren in Theobald's Row, by Red-Lion Square

Mr Owen, a clerk in the East India House

John Lloyd (d. 1737), Blackwell-Hall factor (cloth merchant)

Mr Narsh

George Wanley (d. 1729), goldsmith

Job Matthews, apothecary

a merchant in this city | a cow-keeper in Islington

Revd Mr Morris, of Abergavenny in Monmouthshire

1,000 an in-keeper in St Martin in the Fields

one of the Lord Mayor's officers

[Thomas] Nash, upholsterer

Robert Heysham (1663-1723), MP for London

[Thomas] Snow (d. 1746), partner with [John] Warner (d. 1722), goldsmiths

Arthur Cutting and Thomas Hyeth, cheesemongers

[William] Jenkins, deputy [of Billingsgate ward]

Jenkinson, cheesemonger in Thames Street

[James] Colebrooke and Ruck [Rooke], bankers

[Robert] Spark[e] (d. 1728), ironmonger (to HM), Catherine-St in the Strand

Philip Gibbs (d. 1752), Backwell-Hall Factor (cloth merchant)

Henry O'Brien, earl of Thomond (d. 1741)

a gentlewoman unknown

500 the share of Mr Martin and Company, goldsmiths in Lombard St.

George Wanley, goldsmith (d. 1729)

Dr. John Freind, physician (1675-1728)

a vintner at the Crown, by Guildhall

Glisson Maydwell (d. 1748), glass-seller

David Milne, a great insurer of ships

Mr Jenkins, cheesemonger in Thames St and an orange-merchant's apprentice

Table 9: Some winners of the largest prizes, 1719. Sources: Original Weekly Journal, 10 Oct, 24 Oct, 26 Dec 1719, 2 Jan 1720; Weekly Journal, issues 42, 45-53, 55-56 ; Weekly Packet, issues 380-382, 391; Daily Post, issues 14, 25, 43, 52, 68, 75.

(Daily Post, 26 Feb 1728; British Journal, 23 Nov 1728; Daily Post, 19 Jul 1729). John Goodwyn, winner of the top prize in the 1726 lottery, was a surgeon and later mayor of King's Lynn; he had his portrait painted, holding the winning ticket in hand (Goodwyn 1876). Thomas Walker, winner of the top prize in 1731 , was said to be worth $£ 300,000$ at his death in 1748 (Penny London Post, issue 1017).

Not all winners prospered. Susanna Mountfort, winner of $£ 5,000$ in 1714 , was the daughter of two famous actors and an actress herself at Drury-Lane; not long after, she became insane, and is famous for having once walked onstage in the middle of a performance of Hamlet (in which she was not cast) and recited Ophelia's monologue (Doran $1880,1: 268,272)$. The winner of the 1714 prize was a clergyman, brother to the headmaster of Westminster school. According to his entry in the ODNB, he died in debtor's prison. ${ }^{7}$ John Garway, who won $£ 5,000$ in the 1731 , was a prominent hop, flax and hemp merchant and sail-cloth maker in Worcester; he also won two $£ 1,000$ prizes in the 1737 Bridge lottery but nevertheless went bankrupt in 1749. John Julian, a merchant of Swiss origin who won $£ 5,000$ in the 1743 lottery, died in 1754 and his son and surviving partner was declared bankrupt immediately after (London Evening Post issue 4102, London Gazette issue 9356). The winner of one of the two top prizes in the 1751 lottery, Sir Charles Armand Pawlett,

\footnotetext{
${ }^{7}$ His other brother John, a physician, won a small prize in the 1719 lottery.
} 


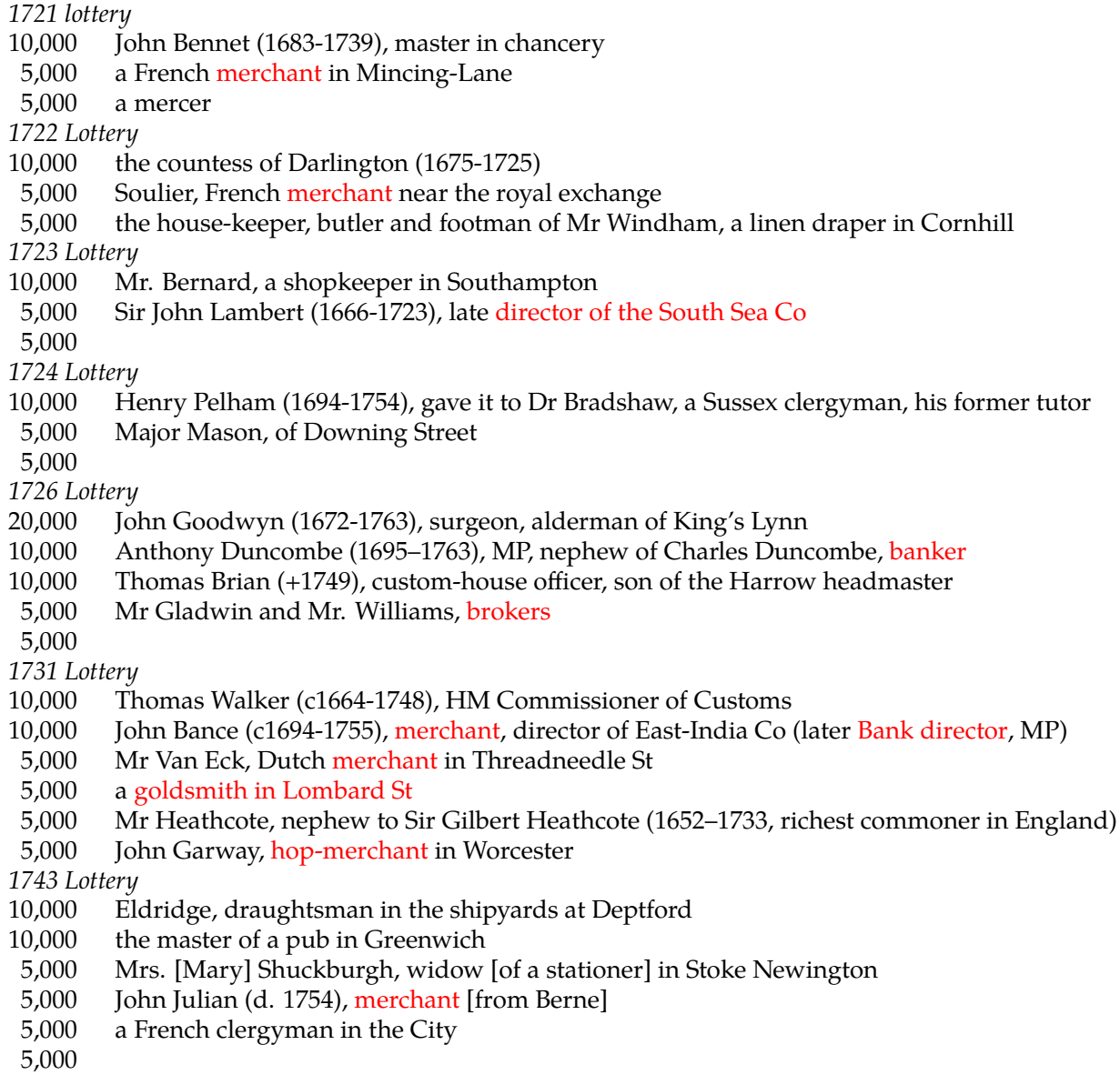

Table 10: Winners of the largest prizes, 1721-43.

died the day his ticket was drawn, although it is not known if there is any causal link (London Daily Advertiser, issue 221, General Evening Post, issue 2806).

What comes out of these lists is that most participants were well-to-do individuals: prominent citizens of London, bankers, merchants, clergymen, military officers, magistrates, tradesmen, clerks, and the occasional nobleman. We also find a butler, a coachman and a few apprentices, but the poor clothier with ten children (Daily Post, 21 Nov 1719, issue 43) seems to be more the exception than the rule. One must however note an interesting report: "The journeymen weavers in Spittle-Fields, having a box in which they contributed weekly money for the relief of such as would be sick, and having 90L in stock, unanimously agreed to buy tickets, and 4 of them are drawn prizes of 10L each, and another 25L, the other 25 as yet undrawn" (Weekly Journal, 17 Oct 1719, issue 46).

The social table of England and Wales in 1688 (Table 7) gives an idea of the income distribution at the time: the mean is $£ 39$, while the median is around $£ 20$ (the statistics for the income distribution in 1759 are very similar, at $£ 46$ and $£ 25$ respectively). At $£ 10$, the price of a lottery ticket was half of median income, or a quarter of average income. But a prize of $£ 10,000$ would yield a perpetual income of around $£ 300-400$, enough to move a winner's dynasty to the top $1-2 \%$ of the income distribution. We also see that almost all the winners belonged to groups with family incomes above the median. 


\section{The 1711 and 1712 class lotteries}

For two lotteries we are fortunate to have more detailed information on investors. For the class lotteries of 1711 and $1712,{ }^{8}$ the act provided that within 70 days of the drawing the claimants were to submit their tickets to the managers of the lottery who were instructed to compile a register of the claimants of prizes and transmit it to the Exchequer. The registers, which have survived (National Archives, E4012600 and E4012599 respectively), contain the names, surnames, addresses and occupations of the claimants. We therefore do not have a listing of all investors, but we have a random sample of $4 \%$ and $9.8 \%$ of the tickets respectively.

A caveat is in order. Whereas the names listed by newspapers are those of individuals who were actually exposed to the lottery risk, we cannot exclude that the individuals listed in the registers owned the ticket at the time that it was drawn. Since the tickets were to the bearer, they could have been traded in the ten weeks after the draw, before they were turned into standing orders. ${ }^{9}$

\begin{tabular}{lrrr}
\hline & 1711 & 1712 & $1711-1712$ \\
Abode (\%) & & & \\
City of London & 44.7 & 53.9 & 49.1 \\
Middlesex & 22.9 & 21.9 & 22.9 \\
Westminster & 14.1 & 11.1 & 12.2 \\
Southwark & 1.8 & 2.0 & 1.8 \\
Other Great Britain & 13.0 & 10.6 & 12.1 \\
Ireland & 0.8 & 0.2 & 0.5 \\
Holland & 1.9 & 0.1 & 0.9 \\
Other Foreign & 0.8 & 0.2 & 0.5 \\
Total & 100.0 & 100.0 & 100.0 \\
\hline Gender (\%) & & & \\
Female & 10.4 & 7.1 & 9.1 \\
Male & 89.2 & 92.9 & 90.6 \\
Neither & 0.5 & & 0.2 \\
Total & 100.0 & 100.0 & 100.0 \\
\hline median age & 46 & 43 & 45 \\
\hline Members of Parliament & 24 & 45 & \\
\hline Minorities (\%) & & & \\
Huguenots & 7.9 & 4.3 & 5.3 \\
Jews & 2.1 & 1.3 & 1.4 \\
Nonconformists & 0.6 & 0.4 & 0.5 \\
\hline Other investments & & & \\
B of E shareholders & 218 & 342 & 476 \\
EIC shareholders & 185 & 294 & 403 \\
\hline total numbers & 620 & 928 & 1400 \\
\hline
\end{tabular}

Table 11: Various characteristics of holders of winning tickets in the 1711 and 1712 lotteries. Sources: NA E 4012599 and E 4012600.

Table 11 present some characteristics of lottery winners. Nearly half resided within the

\footnotetext{
${ }^{8}$ The class lotteries derive their name from the peculiar arrangement of prizes (9 Anne c. 23, 10 Anne c. 26). The pay-offs were grouped into five classes; within each class the number of tickets was greater, the distribution of prizes wider, and the size of the smallest prize larger. The classes of prizes were drawn in succession. Tickets were paid off in the order in which they were drawn, earning $6 \%$ interest in the meantime. The taxes appropriated for the payments were enacted for thirty-two years. It seems that repayment was interrupted in 1718 . In 1720 the vast majority of the remaining prizes were subscribed into South Sea stock.

${ }^{9}$ The 1711 class lottery ended on August 15; the deadline for submitting tickets was October 24, and register E4012600 is dated December 20. The 1712 lottery ended on October 16; for unknown reasons its register is dated much later, 25 Mar 1717.
} 
confines of the City of London, and another third in the rapidly growing areas around it. Country residents (e.g., landed gentry) were few, and foreigners in small numbers. French Protestants, who had been settling in London since 1685, were well represented, as were Jews (mostly Sephardic). Interestingly, a third of the winners appear on listings of Bank of England and East India Company shareholders of the time.

Table 9 confirms what newspaper reports suggest: lottery winners were overwhelmingly drawn from the upper half of the income distribution. ${ }^{10}$ The true aristocracy and landed gentry is not strongly present. The bulk of investors are merchants and former merchants; nearly $4 \%$ are bankers or goldsmiths.

\begin{tabular}{lrrrr}
\hline & 1711 & 1712 & $1711-1712$ & population \\
\hline Temporal Lords & 1.6 & 1.8 & 1.7 & 0.01 \\
Baronets & 2.3 & 1.6 & 1.9 & 0.06 \\
Knights & 1.8 & 2.6 & 2.1 & 0.04 \\
Esquires & 19.7 & 20.4 & 19.5 & 0.22 \\
Merchants & 25.4 & 22.7 & 22.8 & 0.38 \\
Gentlemen & 15.8 & 17.1 & 17.2 & 1.08 \\
Clergymen (Greater) & 1.0 & 0.2 & 0.6 & 0.14 \\
Persons in the Law & 0.7 & 0.1 & 0.3 & 0.58 \\
Persons in Office (Lesser) & 2.1 & 0.5 & 1.1 & 0.36 \\
Naval Officers & 1.1 & 1.3 & 1.4 & 0.36 \\
Persons in Sciences \& Liberal Arts, Military Officers & 1.6 & 1.7 & 1.7 & 1.22 \\
Shopkeepers \& Tradesmen & 15.4 & 19.4 & 18.3 & 7.31 \\
Clergymen (Lesser) & 1.6 & 0.8 & 1.1 & 0.72 \\
Freeholders (Greater) & 0.0 & 0.1 & 0.1 & 1.98 \\
Manufacturing Trades & 2.4 & 3.4 & 3.1 & 11.71 \\
Building Trades & 0.2 & 0.2 & 0.2 & 5.25 \\
Common Seamen & 0.2 & 0.4 & 0.4 & 3.60 \\
Laboring People \& Outservants, Miners & 0.3 & 0.8 & 0.6 & 21.5 \\
Unknown & 6.8 & 4.7 & 6.0 & \\
\hline
\end{tabular}

Table 12: occupations of holders of winning tickets in the 1711 and 1712 lotteries, compared with the general population. Sources: TNA, E 4012599 and E 4012600.

The intersection of politics and finance is particularly interesting for these loans (Carruthers 1996). They were issued shortly after the Whigs, who had governed since the Glorious Revolution, were turned out of office by Queen Anne in 1710 and a new election brought a Tory majority to Parliament. For City of London residents voting lists are available for three nearby years. Investors whose votes can be identified are tabulated in Table 13. For all the bitterness between Whigs and Tories, and the alleged maneuvers by Whigs to hinder the new Tory cabinet's loan issues, there is no visible partisan bias among investors.

From 1719 onward the annuities resulting from the lotteries were paid out by the bank of England. The archives of the bank of England contain the registers with the names of the annuity owners, making it possible to carry out the same kind of investigation for later lotteries. The caveat applies, that these registers list the owners of annuities, who could have bought them from the ticket holders. In a few instances (such as the lottery loan of 1747) the registers list separately the owners of annuities issued from the lottery and the

\footnotetext{
${ }^{10}$ The occupations in the registers are self-reported, and many winners used the vague styles of "esquire" and "gentleman," which meant at the time someone who could afford to live like a gentleman, i.e., comfortably and without working. I have made efforts to identify as much as possible those gentlemen who were still working or recently retired.
} 


\begin{tabular}{|c|c|c|c|c|c|c|c|c|c|c|}
\hline \multirow{2}{*}{$\begin{array}{l}\text { lottery } \\
\text { election }\end{array}$} & \multicolumn{3}{|c|}{1711} & \multicolumn{3}{|c|}{1712} & \multicolumn{3}{|c|}{ either } & \multirow[b]{2}{*}{ all } \\
\hline & 1710 & 1711 & 1713 & 1710 & 1711 & 1713 & 1710 & 1711 & 1713 & \\
\hline Tory & 17 & 4 & 26 & 47 & 13 & 42 & 56 & 14 & 57 & $47.2 \%$ \\
\hline Whig & 22 & 6 & 33 & 34 & 8 & 57 & 53 & 10 & 83 & $44.4 \%$ \\
\hline Split & 2 & 0 & 0 & 7 & 0 & 1 & 8 & 0 & 1 & $8.4 \%$ \\
\hline Total & 41 & 10 & 59 & 88 & 21 & 100 & 117 & 24 & 141 & \\
\hline
\end{tabular}

Table 13: Votes cast in polls in the city of London by winners in the 1711 and 1712 lotteries.

owners of the standard annuities (i.e., the annuities that had been random and those that hadn't), making possible a comparison of the two populations.

\section{Other sources on ticket holders}

The National Archives (IR 551) hold some records related to lost lottery tickets. When a ticket holder lost his ticket he could ask the lottery managers for a replacement but had to submit a bond to hold the managers harmless in case the lost ticket was recovered; along with the bond an affidavit affirming the loss was filed. Only a few are extant (ten between 1711 and 1752, then about ten per lottery from 1763 to 1776). A cursory inspection indicates that the occupations of ticket holders were broadly similar to those found above. $^{11}$

\subsection{Information and Markets}

\section{Information}

Detailed information about the nature of the lotteries was available at the time. The Acts of Parliament authorizing the loans contain the exact number of tickets and prizes, and specify the method and latest possible date for the drawing. The opening of the draw was announced in newspapers. Over the course of the draw, various offices (which advertised their services in the newspapers) kept investors informed of the prizes drawn, sometimes as frequently as every quarter hour; it was also possible to register one's ticket to be informed immediately when it was drawn, for a fee. From the late 1710s, the newspapers also reported when the major prizes were drawn. Once the draw was over, the commissioners of the lottery published an official list of the prizes, and the early lists even include the date at which each prize was drawn. I have used the surviving lists for the early draws, and newspapers accounts for later draws, to collect information on the number of prizes remaining in the wheel day by day.

\section{Intermediation}

The lists of winners also reveal an interesting element: poorer individuals tended to share lottery tickets. This was an obvious way to overcome the relatively high hurdle imposed

\footnotetext{
${ }^{11}$ One might, of course, worry about selection bias-some occupations being more prone to losing lottery tickets than others.
} 
by the ticket price. As one might expect, an industry soon appeared to intermediate the tickets into smaller tickets.

Soon after the 1711 lottery was approved, Thomas Smyth and Jonathan Collyer published a broadside offering a subscription of $\frac{1}{20}$ shares in tickets of the lottery at the price of $10 \mathrm{~s} 6 \mathrm{~d}$ ( $5.25 \%$ of the face value), to purchase up to 2000 tickets in the lottery; the tickets would then be sold on the secondary market within three months after the draw. The proposal noted that if the market price of lottery tickets were to rise, the price of the $\frac{1}{20}$ shares would be adjusted upward. Another proposal was published in Abel Boyer's Supplement (March 9, 1711, issue 492) by Charles Weston and Griffith Lloyd, with a similar price for shares but also allowing a 5\% share in the profits to the undertakers.

Matthew West, a goldsmith in Clare-Street, also advertised a similar scheme in the British Mercury starting in July, with shares selling at 11s, raised to 11s 6d on August 12 because of the rising market price of lottery tickets. This last venture is known to have reached completion, because the shares were paid off in February 1712 (Daily Courant, 21 Feb 1712, issue 3231), although its scale was not very large, since West bought only 100 lottery tickets (British Mercury, 15 Oct 1712, issue 380; Flying Post, 6 Nov 1712, issue 3293). He offered similar schemes in all subsequent lotteries, diversifying into foreign lotteries (Dutch and German) from $1714 .{ }^{12}$ In the 1719 lottery, which was priced at $£ 3$, he offered $\frac{1}{8}$ shares at a $20 \%$ premium.

How extensive was intermediation? The early lists of lottery winners, in which shared tickets are rare, suggests that it was not at first. But as the century advanced it seems to have become more common, while remaining limited. In the 1769 lottery (the first cash lottery), only two of the top twelve prizes were won by intermediated tickets. ${ }^{13}$ Certainly the authorities eventually acknowledged the phenomenon while trying to limit it: the Act authorizing the 1788 lottery ( 28 Geo 3 c. 21) prohibited shares smaller than $\frac{1}{16}$ under penalty of $£ 50$, a provision repeated in later lottery acts, some of which (like 37 Geo $3 \mathrm{c}$. 113) also regulated the form of the contract.

\section{Rental market or repos}

Another way to make the lotteries accessible to smaller incomes was to rent lottery tickets for period of time during the draw. This method appeared in the mid-1720s, and a rented ticket came to be known as a "horse." The contract is described in Mist's Weekly Journal (15 Oct 1726, issue 78): "the term Horse is technical for the chance of a number for a certain time, upon condition (if it draws a prize) or replacing it to the vendor with an undrawn ticket": effectively a repo transaction. The price of a "chance for a day" was quoted in newspapers for the 1726 and 1731 lotteries.

The risk involved in renting a horse is illustrated in Henry Fielding's farce "the Lottery" by the following exchange, taking place in Guildhall during the draw between a

\footnotetext{
${ }^{12} \mathrm{He}$ may have run into temporary legal trouble: in November 1712 subpoenas were issued by the Court of Exchequer against him, as well as other "undertakers, printers and publishers of, and contributors to the several new schemes of lotteries" (Post Boy, 29 Nov 1712, issue 2735). Obviously nothing came of it.

${ }^{13}$ Since intermediators tended to advertise their winning tickets, a systematic study of newspaper advertisements could yield a more accurate assessment of the extent of intermediation.
} 
stock-jobber named Stocks and a coachman:

Coachman. Oh Sir! your worship has let me a very lucky horse: it is come up twenty pound already. So if your worship would let me have the money-Stocks. Let me see, tickets are this day nineteen pound; and your prize is worth eighteen pound eighteen shillings; so if you give me two shillings, which are the difference, we shall be quit. Coachman. How, Sir! how! Stocks. Upon my word, friend, I state the account right. Coachman. Oh,- - the devil! and have I given three pound for the chance of losing two shillings more? Stocks. Alas, Sir! I cannot help ill fortune.-You have had ill luck; it might have come up a hundred, or a thousand, or ten thousand.

(Henry Fielding: "The Lottery")

These practices were made illegal in 1737 , and the prohibitions routinely included in all subsequent lottery acts.

\section{Options}

One enigmatic report in Houghton's Collection for the improvement of husbandry and trade (13 Jul 1694) presents prices for what must be derivatives contracts based on the Million lottery, before the draw: they are called "all or any", "all or none", "put", and "refuse": the last two names refer to options (now called put and call). I have not found anything similar in the later lotteries, although one encounters "strips," or the buying of chances, a contract which gave the right to the prize less the price of the ticket. ${ }^{14}$ These contracts are priced before the draw in Freke's Courant in 1714.

\section{Insurance}

Perhaps the most exotic derivative was called "lottery insurance." a paradoxical name for an instrument that makes sense when investors care about more than just first moments.

The 1719 lottery was somewhat different from the previous ones in two respects. First, the ticket price was $£ 3$, a third smaller than the normal lotteries at $£ 10$ and significantly smaller than the classes lotteries at $£ 100$. Second, the blanks received nothing: less was ventured, but it could be completely lost. In the earlier lotteries (as well as in all subsequent ones), blanks received something.

This potential loss appears to have spurred the growth of a market for insurance. Insuring lottery tickets was not new, either in England or elsewhere (see Pepys 1894, 4:92 for insurance on a private lottery in 1664). In the Netherlands, John Law made a business insuring tickets in the Dutch lotteries of 1713 . But the terms of the 1719 lottery prompted the advertisement of several rival schemes in London papers. In the Daily Courant of August 1719 (issues 5565 to 5571), Richard Turner and John Marke, two goldsmiths in Exchange Alley, offered to insure lottery tickets against drawing blank, in which event they would pay the insured $£ 3$. The premium was 22.5 s per ticket for 50 tickets or more, and $25 \mathrm{~s}$ for 25 to 49 tickets. At the same time, the Company of Mines Royal and Mineral and Battery

\footnotetext{
${ }^{14}$ The National Archives, T 1/169/32, preserve an early advertisement for buying chances in the 1713 lottery. The Lord of the Treasury did "not think he should meddle in this matter," suggesting a hands-off approach.
} 
Works (a moribund mining company that had been turned into a vehicle for insurance business by Richard Onslow) considered but declined to offer lottery insurance. Instead, a subscription was opened to raise $£ 120,000$ for that purpose in a separate vehicle. The subscription was completed in two days and terms were offered on August 26. The fund offered to insure sets of $n=12,24,48$ or 96 tickets. The owner handed over the set to the fund, which issued a receipt with the ticket numbers. After the draw, the value of the tickets in $v$ the set would be computed, the tickets returned to their owner, and the fund would pay out $\max \{0,3 n-v\}$. The insurance premium depended on the size of the set. The insured could choose to pay a lower premium in exchange for ceding $5 \%$ of the set's realized value.

Table 14 shows the premia charged, the insurer's expected pay-out, and profits.

\begin{tabular}{lcccc}
\hline size of set & 96 & 48 & 24 & 12 \\
\hline premium $(£ /$ ticket $)$ & & & & \\
with 5\%: $p_{1}$ & 0.8 & 0.95 & 1.1 & 1.25 \\
without: $p_{2}$ & 0.9 & 1.05 & 1.2 & 1.375 \\
insurer's expected $\operatorname{profit}(£ /$ ticket $)$ & & & & \\
with $5 \%: p_{1}-E(\max \{0,3 n-v\} / n)+E(.05 v \mid v>3 n) / n$ & 0.60 & 0.40 & 0.31 & 0.30 \\
without: $p_{2}-E(\max \{0,3 n-v\} / n)$ & 0.57 & 0.34 & 0.16 & 0.10 \\
\hline
\end{tabular}

Table 14: Profitability of the insurance scheme, 1719 lottery. Notation: $v$ is the realized value of a set, $p_{i}$ the premium charged, $n$ the number of tickets in a set.

\subsection{Secondary markets}

Once the subscription closed (and sometimes before), market prices for the tickets appear in contemporary newspapers, alongside prices for stocks and government bonds. Table 15 lists the sources. Prices were quoted for the lottery tickets during the course of the draw, which took anywhere from one to three months, and also for blanks and prizes. Of course, after the draw, the blanks and prizes represented straight government bonds.

\subsection{Prices}

There are also anecdotal reports relating to purchases on the secondary market for the 1719 lottery. The Weekly Journal (5 Dec 1719, issue 53) reported that "a gentlewoman unknown came in a coach to Exchange-Alley, and bought the ticket numbered 102114 which the next day came up a prize of $£ 1,000$." It was also reported (ibid., 17 Oct 1719, issue 46) that Mr. Cox, who won one of the top top prizes, "had but two tickets in the lottery which he bought a month ago for $£ 218$ s each."

The papers reported also on the movement in prices during the draw.

There is no official source for the market prices: the quotes reported in the contemporary newspapers are presumably gathered in and around Exchange Alley where financial transactions took place. Some newspapers (the morning papers) report the previous evening's quotations; the evening papers report the prices as they stood at noon or 1 o'clock. 


\begin{tabular}{|c|c|c|}
\hline \multirow[t]{2}{*}{ Lottery } & \multicolumn{2}{|c|}{ Sources } \\
\hline & Prices & Draw \\
\hline 1694 & $\begin{array}{l}\text { Houghton's Collection for the Improvement } \\
\text { of Husbandry and Trade }\end{array}$ & \\
\hline 1710 & $\begin{array}{l}\text { Post Master, Evening Post, } \\
\text { British Mercury (from } 4 \text { Oct 1710) }\end{array}$ & Daily Courant, 29 Sep 1710 \\
\hline 1711 & British Mercury & Rhodes (1711a) \\
\hline 1711 (class) & British Mercury & Rhodes (1711b) \\
\hline 1712 & $\begin{array}{l}\text { Daily Courant, Evening Post } \\
\text { issues 512-539, British Mercury }\end{array}$ & \\
\hline 1712 (class) & Daily Courant & \\
\hline 1713 & $\begin{array}{l}\text { Post Boy, British Mercury, } \\
\text { Course of the Exchange }\end{array}$ & \\
\hline 1714 & $\begin{array}{l}\text { British Mercury, Course of the Exchange, } \\
\text { Freke's Courant }\end{array}$ & An Account (1715) \\
\hline 1719 & $\begin{array}{l}\text { Weekly Packet, Whitehall Evening, } \\
\text { Post, Post Man, Course of the Exchange }\end{array}$ & An Account (1719) \\
\hline 1721 & Daily Journal & Evening Post, \\
\hline 1722 & Daily Journal & $\begin{array}{l}\text { Daily Journal, Evening Post, } \\
\text { London Journal }\end{array}$ \\
\hline 1723 & Daily Journal, Daily Post & $\begin{array}{l}\text { Evening Post, Weekly Journal } \\
\text { or British Gazetteer }\end{array}$ \\
\hline 1724 & Daily Journal , Daily Post & $\begin{array}{l}\text { Parker's London News, } \\
\text { Original London Post }\end{array}$ \\
\hline 1726 & Daily Journal , Daily Post & Parker's Penny Post \\
\hline 1731 & $\begin{array}{l}\text { Daily Advertiser, London Evening Post, } \\
\text { Daily Post }\end{array}$ & Parker's Penny Post \\
\hline 1743 & Daily Advertiser, Daily Post & Westminster Journal \\
\hline 1744 & Course of the Exchange & Westminster Journal \\
\hline $1745-47$ & General Advertiser, Course of the Exchange & General Advertiser \\
\hline 1748 & Course of the Exchange & General Advertiser, Remembrancer \\
\hline 1751 & Course of the Exchange & London Evening Post \\
\hline 1755 & Course of the Exchange & $\begin{array}{l}\text { London Evening Post, } \\
\text { Read's Weekly Journal }\end{array}$ \\
\hline 1756 & Course of the Exchange & Read's Weekly Journal \\
\hline 1758 & Public Advertiser & Lloyd's Evening Post \\
\hline 1759 & Public Advertiser & Read's Weekly Journal \\
\hline 1760 & Public Advertiser & Lloyd's Evening Post \\
\hline 1761 & Public Advertiser & Lloyd's Evening Post \\
\hline 1763 & Public Advertiser, Course of the Exchange & Lloyd's Evening Post \\
\hline 1765 & Public Ledger & Lloyd's Evening Post \\
\hline 1766 & Gazetteer and New Daily Advertiser & London Evening Post \\
\hline 1767 & Gazetteer and New Daily Advertiser & $\begin{array}{l}\text { London Evening Post, } \\
\text { Lloyd's Evening Post }\end{array}$ \\
\hline 1768 & Lloyd's Evening Post, St James's Chronicle & Lloyd's Evening Post \\
\hline 1776 & Daily Advertiser & New Morning Post \\
\hline
\end{tabular}

Table 15: Sources for market prices and draws. 


\section{Analysis of the prices}

\subsection{The Data}

The data I analyze concern 26 lotteries: the $1711 £ 10$ lottery and all lotteries from 1714 except the 1755 lottery for which price data is insufficient.

First, newspaper reports give me daily price observations for each lottery; the length of the series depends on the duration of the draw and ranges from 25 to 89 . In addition, newspaper reports provide information on the prizes remaining in the wheel at the end of each drawing day. This allows me to reconstruct the distribution of remaining prizes. Oftentimes the count of lowest (hence most common) prizes ( $£ 10$ or $£ 20$ ) are not reported, and I assume that the law of large numbers applies.

\section{The underlying bonds}

As noted above, the lotteries I am studying are not cash lotteries. The ticket prices quoted in the sources are cash prices, but a prize of $£ N$ is in fact a bond with a face value of $£ N$. I therefore need a market value for that bond.

For the later lotteries (1743 to 1776), the lottery's prizes were composed of bonds that were being issued simultaneously in a non-random form, of that were already in existence. In the former case we can readily find market prices for exact underlying bond; in the latter case, the bonds being perpetual redeemable annuities at the same rate, there is no difference between the two issues.

For the earlier lotteries, the underlying bonds may not have an exact counterpart in the secondary market; also, the farther back in time one goes the less price information there is. Fortunately, blank tickets often appear on the secondary market, usually within a week or two of the beginning of the draw. This gives me an exact price of the underlying bond.

When blanks aren't priced I have to use another bond. For the period 1711-14, I use the blank tickets of the 1710 lottery, which remained quoted in the secondary market until their complete redemption in the 1740s. The 1711-14 underlying bonds are not exactly of the same type as the annuity of 1710 , which promised a fixed annual payment for 32 years. Rather, they were 32-year bonds with a fixed coupon and random redemption date, but in expected value the stream of payments is also a 32-year constant payment. Of course, a 1710 blank in 1714 had less than 32 years to run, and I adjust for that. ${ }^{15}$ For 1719 I use quotations for a $4 \%$ redeemable annuity.

\subsection{PDFs and prices}

Table 16 reports the financial characteristics of the loans. The ticket price is the cash value of the ticket. The mean pay-off is the average face value of the bonds given out as prizes (for

\footnotetext{
${ }^{15}$ Specifically, the price of the 1710 blank, divided by 0.7 , is the price of a $£ 1$ annuity until 1743 . A bond with a coupon of $r$ and reimbursement of $£ 1$ over $T$ years is the same as a $£ r e^{r T} /\left(e^{r T}-1\right)$. The 1711 tickets bore $6 \%$ until repayment; the 1714 blanks bore $5 \%$ while the prizes bore $4 \%$.
} 


\begin{tabular}{|c|c|c|c|c|c|c|c|c|c|c|c|}
\hline \multirow[b]{2}{*}{ Lottery } & \multirow[b]{2}{*}{$\begin{array}{l}\text { ticket } \\
\text { price }\end{array}$} & \multirow[b]{2}{*}{$\begin{array}{l}\text { mean } \\
\text { pay-off }\end{array}$} & \multirow[b]{2}{*}{$\begin{array}{l}\text { lowest } \\
/ \text { mean }\end{array}$} & \multirow[b]{2}{*}{$\begin{array}{c}\% \\
\text { blanks }\end{array}$} & \multirow[b]{2}{*}{ std } & \multirow[b]{2}{*}{$\sigma / \mu$} & \multirow[b]{2}{*}{ skew } & \multicolumn{2}{|c|}{1 st 2 weeks } & \multicolumn{2}{|c|}{ last week } \\
\hline & & & & & & & & $\begin{array}{l}\mathrm{mkt} \\
\text { price }\end{array}$ & premium & $\begin{array}{l}\text { mkt } \\
\text { price }\end{array}$ & premium \\
\hline 1694 & 10 & 13.75 & 0.73 & 0.98 & 63.0 & 4.58 & 86.0 & 10 & 0.12 & & \\
\hline 1710 & 10 & 9.00 & 0.78 & 0.98 & 47.0 & 5.22 & 114.7 & 10.84 & 0.22 & 10.78 & 0.21 \\
\hline 1711 & 10 & 12.86 & 0.78 & 0.83 & 49.7 & 3.86 & 136.6 & 13.20 & 0.15 & 11.00 & 0.20 \\
\hline $1711^{*}$ & 100 & 130.11 & 0.85 & 0.96 & 165.4 & 1.27 & 92.6 & 105.35 & 0.08 & 100.75 & 0.04 \\
\hline 1712 & 10 & 13.01 & 0.77 & 0.83 & 61.7 & 4.74 & 141.5 & 102.84 & 0.16 & 110.31 & 0.11 \\
\hline $1712 *$ & 100 & 130.10 & 0.81 & 0.90 & 175.0 & 1.35 & 86.8 & 98.55 & 0.11 & 95.48 & 0.04 \\
\hline 1713 & 10 & 12.66 & 0.79 & 0.86 & 72.5 & 5.73 & 116.6 & 10.43 & 0.37 & 10.42 & 0.37 \\
\hline 1714 & 10 & 13.40 & 0.75 & 0.83 & 78.5 & 5.86 & 160.2 & 10.38 & 0.13 & 11.01 & 0.15 \\
\hline 1719 & 3 & 2.96 & 0.00 & 0.83 & 68.0 & 22.95 & 200.6 & 3.50 & 0.18 & 3.15 & 0.06 \\
\hline 1721 & 10 & 10.50 & 0.76 & 0.90 & 54.8 & 5.22 & 117.0 & 10.82 & 0.03 & 10.49 & 0.00 \\
\hline 1722 & 10 & 10.50 & 0.76 & 0.90 & 54.8 & 5.22 & 117.0 & 11.42 & 0.09 & 11.06 & 0.05 \\
\hline 1723 & 10 & 10.18 & 0.74 & 0.90 & 53.4 & 5.24 & 118.2 & 10.68 & 0.05 & 10.91 & 0.07 \\
\hline 1724 & 10 & 10.18 & 0.74 & 0.90 & 53.4 & 5.24 & 118.2 & 10.93 & 0.07 & 11.34 & 0.11 \\
\hline 1726 & 10 & 10.00 & 0.75 & 0.92 & 86.0 & 8.60 & 163.0 & 13.90 & 0.39 & 12.68 & 0.27 \\
\hline 1731 & 10 & 10.00 & 0.75 & 0.90 & 67.1 & 6.71 & 107.7 & 10.74 & 0.07 & 11.77 & 0.18 \\
\hline 1743 & 10 & 10.00 & 0.70 & 0.88 & 67.4 & 6.74 & 106.4 & 11.13 & 0.11 & 11.02 & 0.10 \\
\hline 1744 & 10 & 10.00 & 0.60 & 0.84 & 75.5 & 7.55 & 98.6 & 11.95 & 0.19 & 12.06 & 0.21 \\
\hline 1745 & 10 & 10.00 & 0.60 & 0.86 & 80.1 & 8.01 & 94.5 & 12.57 & 0.26 & 11.93 & 0.19 \\
\hline 1746 & 10 & 10.00 & 0.60 & 0.86 & 80.1 & 8.01 & 94.5 & 11.54 & 0.15 & 11.18 & 0.12 \\
\hline 1747 & 10 & 10.00 & 0.60 & 0.86 & 80.1 & 8.01 & 94.5 & 10.93 & 0.09 & 11.11 & 0.11 \\
\hline 1748 & 10 & 10.00 & 0.60 & 0.86 & 85.4 & 8.54 & 90.8 & 11.32 & 0.13 & 11.84 & 0.18 \\
\hline 1751 & 10 & 10.00 & 0.60 & 0.86 & 76.6 & 7.66 & 86.3 & 11.51 & 0.15 & 11.76 & 0.18 \\
\hline 1755 & 10 & 9.00 & 0.67 & 0.96 & 61.1 & 6.79 & 112.7 & 10.01 & 0.11 & 10.29 & 0.14 \\
\hline 1756 & 10 & 10.00 & 0.60 & 0.87 & 80.8 & 8.08 & 92.4 & 13.14 & 0.31 & 13.45 & 0.34 \\
\hline 1758 & 10 & 10.00 & 0.60 & 0.87 & 80.8 & 8.08 & 92.4 & 11.45 & 0.15 & 12.55 & 0.26 \\
\hline 1759 & 10 & 10.00 & 0.60 & 0.86 & 117.5 & 11.75 & 152.3 & 13.51 & 0.35 & 14.65 & 0.46 \\
\hline 1760 & 3 & 3.00 & 0.00 & 0.83 & 60.1 & 20.02 & 132.4 & 5.37 & 0.79 & 5.89 & 0.96 \\
\hline 1761 & 10 & 10.00 & 0.60 & 0.80 & 68.8 & 6.88 & 117.0 & 14.85 & 0.48 & 15.77 & 0.58 \\
\hline 1763 & 10 & 10.00 & 0.50 & 0.83 & 90.4 & 9.04 & 88.6 & 14.07 & 0.41 & 12.99 & 0.30 \\
\hline 1765 & 10 & 10.00 & 0.60 & 0.80 & 68.8 & 6.88 & 117.0 & 13.85 & 0.38 & 13.18 & 0.32 \\
\hline 1766 & 10 & 10.00 & 0.60 & 0.80 & 68.8 & 6.88 & 117.0 & 13.47 & 0.35 & 13.11 & 0.31 \\
\hline 1767 & 10 & 10.00 & 0.00 & 0.64 & 120.8 & 12.08 & 109.5 & 14.31 & 0.43 & 14.70 & 0.47 \\
\hline 1768 & 10 & 10.00 & 0.00 & 0.67 & 152.8 & 15.28 & 96.6 & 16.45 & 0.64 & 16.74 & 0.67 \\
\hline 1776 & 10 & 10.00 & 0.00 & 0.67 & 148.0 & 14.80 & 101.3 & 13.78 & 0.38 & 14.60 & 0.46 \\
\hline
\end{tabular}

Table 16: Financial characteristics of the loans. *: class lotteries. Prices are cash while pay-offs are expressed in face value of bonds (see text).

the 1694 and 1710 lotteries, it is 10 times the average value of the term annuities issued). To compare prices and mean pay-offs one needs market prices of the bonds (see below).

The next five columns are statistics of the distribution of prizes: ratio of lowest payoff to mean pay-off, proportion of blanks (tickets receiving the lowest pay-off), standard deviation, coefficient of variation, and skewness. What appears from this table is that the government never settled on a fixed format for its lotteries, but rather continuously varied the terms. There is a general trend for the share of blanks to decrease over time, but the second and third moments of the prize distribution vary substantially. The 1719 and 1760 lotteries stand out by these measures because the blanks received no pay-off. This was also true of the last three lotteries but there were fewer blanks (2/3 instead of $83 \%)$.

The last columns provide information on the market prices of the lottery tickets, at two points in time: during the first two weeks for which prices are available (typically after the subscription had sold out), and in the week before the draw. The market price reported is normalized by the market value of the underlying bond: in other words, it says how much of the underlying bond could be bought on the same day with a cash amount equal to the market price of the ticket. Hence it is directly comparable to the prizes. The premium is computed relative to the mean pay-off in the second column: it shows how much investors were willing to pay in order to receive their bond in lottery form rather than its certainty equivalent. This premium is always positive, and in the last years it is considerable.

The goal of this paper is to make sense of these premia. 

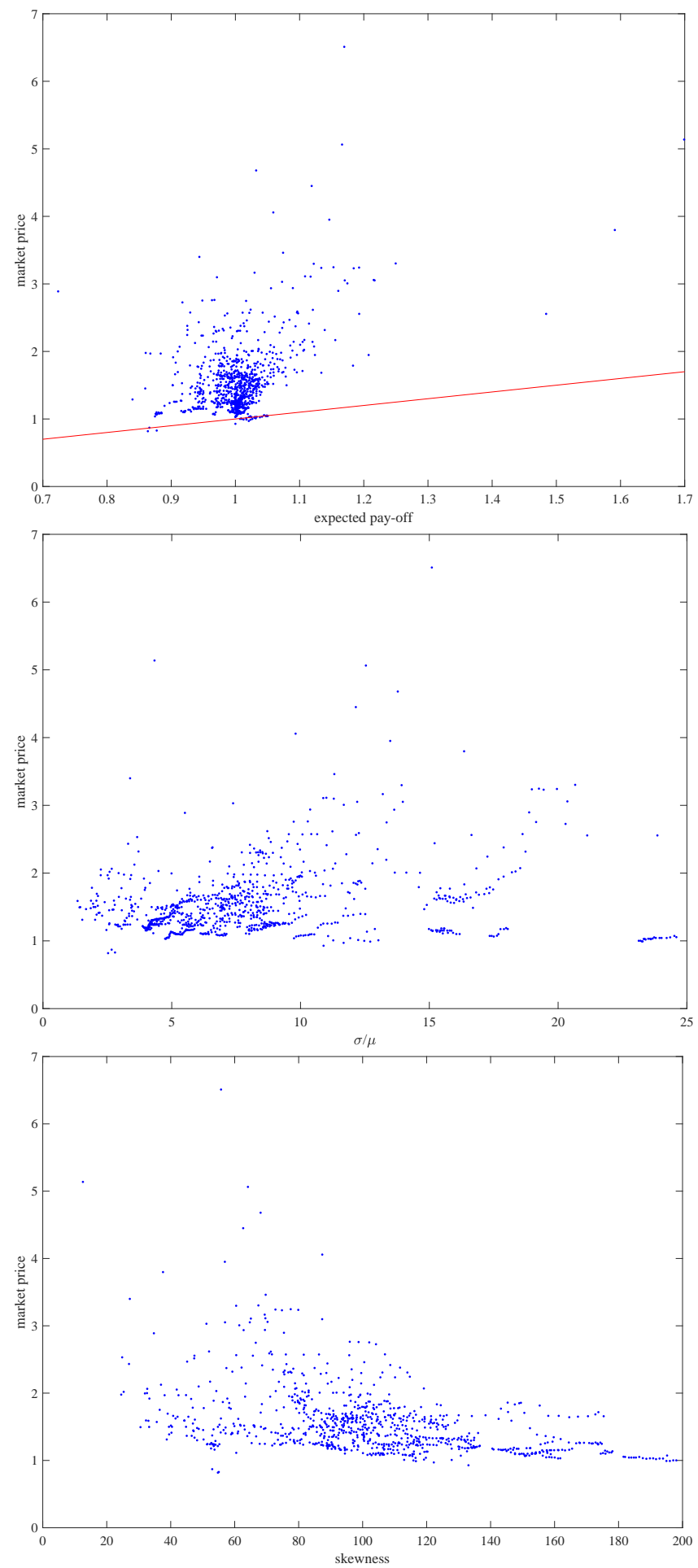

Figure 2: Mean, coefficient of variation and skewness of prizes compared to market prices.

\section{Moments and Time Series}

Figure 2 compares the first three moments of the prize distributions with market prices. The negative returns are obvious from the top panel. Neither the middle nor the bottom panel show any pattern.

Figure 3 shows that, over the course of a lottery's draw, prices tended to rise significantly. 


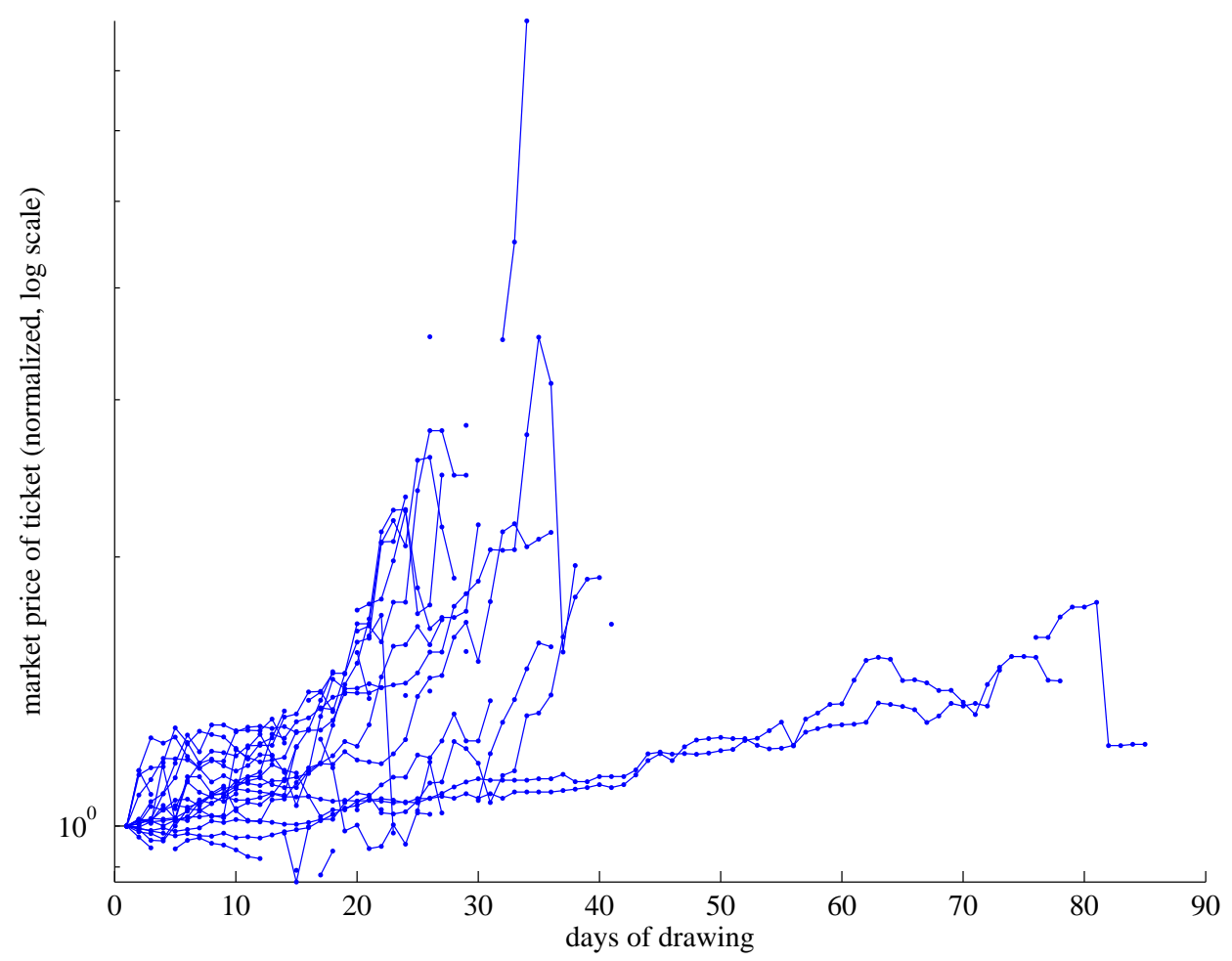

Figure 3: Evolution of prices over the course of the draws. 


\subsection{Summary of facts}

The British government offered securities that were, in effect, a lottery whose pay-off was in the form of other, standard government bonds. The government did so repeatedly over the course of the 18th century. A sizeable portion (up to 25\%) of the flow of new debt was issued in this form, so this type of instrument was not anecdotal. In terms of the stock of debt, however, these lotteries did not represent a large component of investor portfolios, except in the very first years: the 1710 lottery represented $7.5 \%$ of the public debt, the 1726 lottery represented $2 \%$, and the 1768 lottery $0.5 \%$. Moreover the randomness was not a permanent component of the security: soon after issue, a draw determined the size of the bond delivered to each investor; after the draw, portfolios "returned to normal."

The risk associated with the lotteries was perfectly exogenous and orthogonal to every other source of risk. It was perfectly known by all investors, who could easily find out (both before and during the draw) the exact probability distribution, and who had no reason to doubt it. It was a purely artificial risk that provided no hedge of any kind.

From an examination of the lottery winners, it appears that purchasers of these lotteries (from whom the winners were by construction randomly selected) were well-to-do and savvy individuals, and there is nothing to suggest that they were any different from other investors.

Market prices are available for these lotteries. The most striking observation is that the price of a lottery ticket was larger, sometimes substantially so, than the market value of its expected pay-off. Investors were willing to pay to randomize the size of a bond.

The randomization was substantial, with high variance and high skewness. The ticket price represented a half of median income, the top prize could reach a thousand times median income. The government appeared constantly to experiment with the design of the probability distribution. That investors had specific preferences over the probability distribution is also suggested by the private insurance market, which in effect rearranged the distribution for a fee.

The price observations have two dimensions: we have observations for a number of lotteries over the years, and for each lottery we have observations over the course of the draw. As prizes are drawn the distribution of the lottery changes in a known way, but (since drawing is without replacement) the market size shrinks steadily over the course of the draw. it appears that the premium paid for lottery tickets (over their expected value) trended upward systematically over the course of the draw. Nonetheless, casual observation shows that market prices responded to changes in the distribution (drawing big prizes led to a fall in market prices of undrawn tickets).

It is important to note that short-selling these securities was difficult. The Act for Suppressing of Lotteries (10 Will 3 c. 23) passed in 1699 recited that "several evil disposed persons" have set up "many mischievous and unlawful games called Lotteries," it declared lotteries "common and public nuisances" and prohibited anyone from setting them up. The Act was strengthened a few years later (9 Ann c. 6, s. 57) and remained in force until updated by the Betting and Lotteries Act (1934). Furthermore betting on the outcome of 
the official government lottery was made illegal in 1719 (5 Geo I c. 9 s. 43).

\subsection{Accounting for the observations: Cumulative prospect theory preferences}

To make sense of these observations standard expected utility with concave preferences will not get me very far, which is why I turn to an alternative specifications, namely cumulative prospect theory (CPT).

Cumulative prospect theory (CPT) is a variant of prospect theory. The objective function assigned to individuals

$$
\sum_{i=-m}^{n} \pi_{i} v\left(x_{i}\right)
$$

has two features: (a) a value function $v\left(x_{i}\right)$ defined over gains and losses $x_{i}$, relative to a reference value (say, current wealth), and (b) a weighting function $\pi_{i}(p)$ that distorts the objective probabilities $p=\left\{p_{i}\right\}$ of gains and losses.

In CPT the value function $v$ is concave over gains, convex over losses, and kinked at 0 . As for the weighing function $\pi_{i}$, it is a function of the cumulative probability distribution (in contrast to prospect theory, in which it was a function of the probabilities).

Specifically, for a lottery ordered from largest loss to largest gain: $\left(x_{-m}, p_{-m} ; \ldots\right.$; $\left.x_{-1}, p_{-1} ; x_{0}, p_{0} ; x_{1}, p_{1}, \ldots ; x_{n}, p_{n}\right)$, weighting depends on cumulative probability distribution:

$$
\pi_{i}= \begin{cases}w^{+}\left(p_{i}+\ldots+p_{n}\right)-w^{+}\left(p_{i+1}+\ldots+p_{n}\right) & 0 \leq i \leq n \\ w^{-}\left(p_{-m}+\ldots+p_{i}\right)-w^{+}\left(p_{-m}+\ldots+p_{i-1}\right) & -m \leq i \leq 0\end{cases}
$$

Tversky and Kahneman (1992) propose the following functional forms

$$
v(x)= \begin{cases}x^{\alpha}, & x \geq 0 \\ -\lambda(-x)^{\beta}, & x<0\end{cases}
$$

and

$$
\left\{\begin{array}{l}
w^{+}(p)=\frac{p^{\gamma}}{\left(p^{\gamma}+(1-p)^{\gamma}\right)^{1 / \gamma}} \\
w^{-}(p)=\frac{p^{\delta}}{\left(p^{\delta}+(1-p)^{\delta}\right)^{1 / \delta}}
\end{array}\right.
$$

When the CDF $P(x)$ is continuous over outcomes $x$, the objective function takes the form:

$$
U(x)=\int_{-\infty}^{0} v^{-}(x) \frac{d w^{-}}{d p}(P(x)) d P(x)-\int_{0}^{+\infty} v^{+}(x) \frac{d w^{+}}{d p}(1-P(x)) d P(x)
$$

The five parameters $(\alpha, \beta, \lambda, \gamma, \delta)$ respectively govern the concavity over gains, the convexity over losses, the kink between small gains and losses, and the overweighting of left-tail and right-tail events. ${ }^{16}$ Tversky and Kahneman (1992) estimate $\alpha=\beta=0.88, \lambda=2.25$, $\gamma=0.61, \delta=0.69$.

Barberis and Huang (2008) present an equilibrium model with identical investors whose preferences conform to cumulative prospect theory (CPT). In their static set-up, of in-

\footnotetext{
${ }^{16}$ Another, popular specification of weighting is $\delta p^{\gamma} /\left(\delta p^{\gamma}+(1-p)^{\gamma}\right)$ (Goldstein and Einhorn 1987). I did not explore it because it adds another parameter to estimate.
} 
vestors with CPT-preferences, which are assumed to take the functional forms above with $\alpha=\beta$ and $\gamma=\delta$. The available assets are a risk-free asset, a set of $J$ assets with multivariate normal pay-offs in fixed supply, and one skewed security (the lottery $L$ ), independent of the other assets, in infinitesimal supply.

They prove by example that an equilibrium can exist in which the skewed security earns a negative excess return. Let $x$ be the share of the investor's portfolio invested in the lottery, the rest invested in a linear combination of the risk-free asset and the tangency portfolio formed from the $J$ risky assets. The equilibrium is characterized by an indifference of investors between not holding the lottery $(x=0)$ or holding a certain amount $x^{*}$, at the market prices for the lottery $p_{L}$ and the tangency portfolio $p_{J}$. Let $V\left(x, p_{L}, p_{J}\right)$ be the valuation of a portfolio valuation of the portfolio $(x, 1-x)$ by each CPT investor. The equilibrium conditions thus boil down to $V\left(0, p_{L}, p_{J}\right)=0, V\left(x^{*}, p_{L}, p_{J}\right)=0$, and $V^{\prime}\left(x^{*}, p_{L}, p_{J}\right)=0$. The first equation allows to solve for price of the $J$ normal portfolio $p_{J}$ (since $x=0$, the price of the lottery $p_{L}$ doesn't enter the equation), and the other two become $V\left(x^{*}, p_{L}\right)=0$, and $V^{\prime}\left(x^{*}, p_{L}\right)=0$. There are two variables to solve for: the price of the lottery $p_{L}$ and the share $x$. Given the assets' pay-offs (the standard deviation $\sigma_{J}$ and the distribution of prizes $L$ of the lottery), the equilibrium conditions can be represented as $F\left(x, p_{L} \mid \gamma, \lambda, \alpha, \sigma_{J}, L\right)=0$.

\section{Estimation}

In the data I do not observe $p_{J}$ or $x$, although I have a sense of what reasonable values could be. I do observe a collection $\left\{L_{i t}, p_{L_{i t}}\right\}$ of lotteries and their market prices, where $t$ represents years, and $i$ are successive observations over the course of each year's draw. The equilibrium model give me a mapping from lottery $L$ to price $p$ given preference parameters $\{\gamma, \lambda, \alpha\}$ and variance of market portfolio $\sigma_{J}$. The general strategy is to search for parameters such that the equilibrium prices of the lotteries in the model $\hat{p}_{L_{i t}}$ are as close as possible to the actual prices (i.e., minimize the sum of squared deviations). This requires repeatedly solving for the equilibrium of the model for each lottery. ${ }^{17}$

I calibrate the variance of the market portfolio $\sigma_{J}$ and estimate the three preference parameters $(\gamma, \lambda, \alpha)$. The Bank of England and East India Company stock were the most commonly traded forms of equity in 18th c. London. The standard deviation of returns is 0.10 for the former and 0.15 for the latter, while the excess return is $6.1 \%$ and $7.5 \%$.

There are about 1000 observations for the period from 1711 to 1776 . As a first step, I estimate constant preferences over the whole period using a small subset of observations, namely, the average market price in the last week before each lottery's draw: in other words, one price observation for each lottery loan, assumed to price the full set of prizes available before the draw began.

The estimates I find are $(\gamma, \lambda, \alpha)=(0.76,1.64,0.84)$, quite similar to the values found by Tversky and Kahneman (1992) of $(0.65,2.25,0.88)$. For $\gamma$, the value is also well in the

\footnotetext{
${ }^{17}$ My strategy differs from Eraker and Ready (2013), who do not search for values of the parameters that would explain the pricing of OTC stocks, but instead compute the equilibrium price under the Tversky and Kahneman (1992) parameter values and measure the fit of the model by comparing the difference between predicted and actual returns with the standard error of a CAPM regression.
} 
range found by the experimental literature (Etchart-Vincent 2009, Table 4).

The predicted and actual prices are shown in Figure 4. The model can account for the market premium on lotteries, while still pricing the Gaussian asset sensibly (the model's predicted excess return is $3.97 \%$ ).

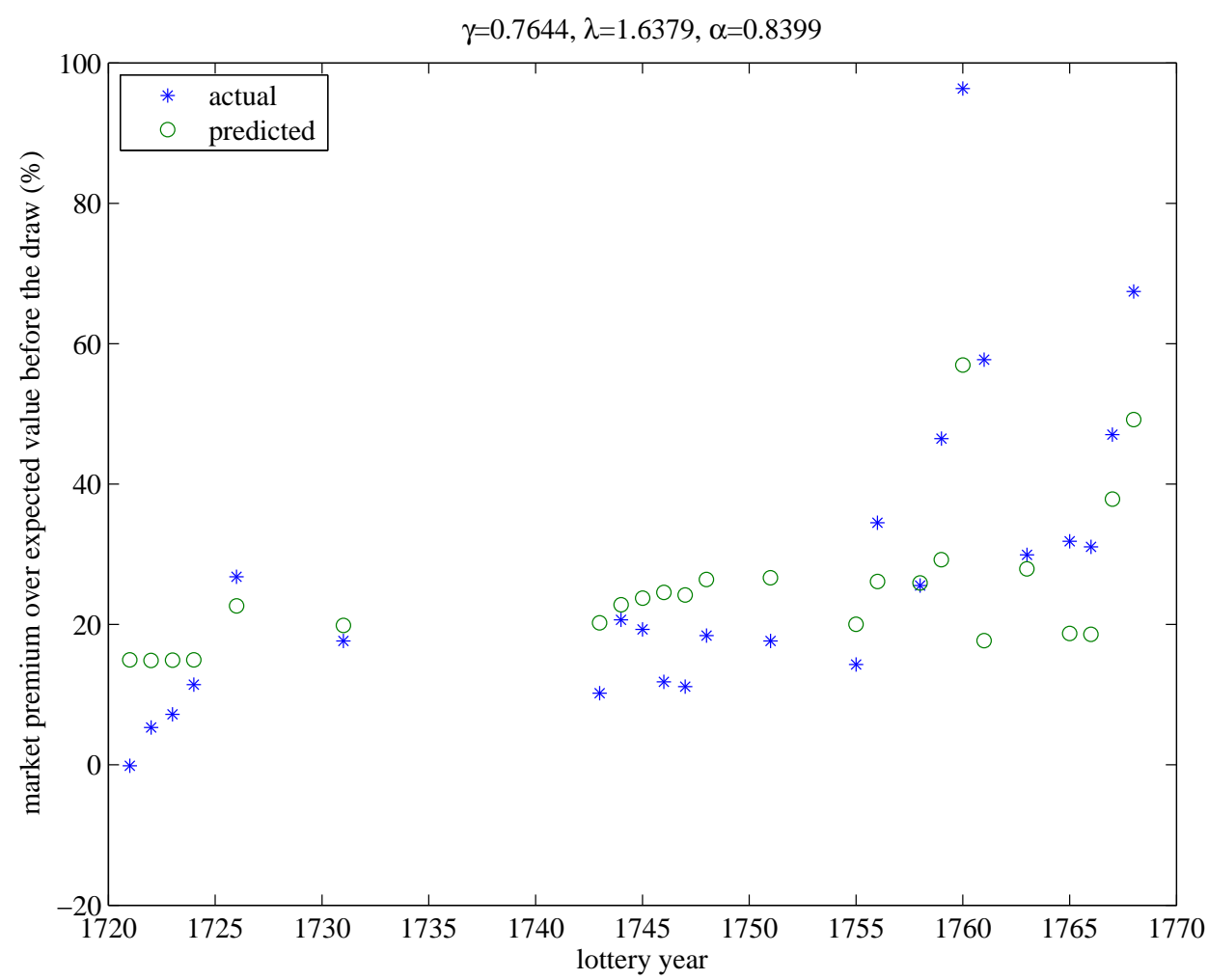

Figure 4: Predicted and actual lottery prices, last week before the draw.

I then estimate the preference parameters $(\gamma, \lambda, \alpha)$ for each of the available lottery loans. That is, instead of assuming constant preferences over the whole 18th century, I only assume them to be constant during each of the lottery's draw. As the draw unfolds, the variation in the prizes remaining in the wheel induces variation in the market price, hopefully sufficient to recover the parameters. I use the preliminary estimates found earlier as starting values for the parameters.

You are now entering a construction zone. Proceed with caution.

I initially fixed $\sigma=0.15$ and proceeded to estimate all three parameters. It became apparent, both from comparing the results across lotteries, and from observing the search algorithm for each lottery, that $\lambda$ (the kink in the value function at 0 , or sensitivity to small losses) is poorly identified. This is not surprising because there is almost no variation in the data on losses: the left tail of the prize distribution almost never varies because the law of large numbers keeps the number of blanks (the smallest prizes) nearly constant over the course of the draw. The only variation is across years, due to changes in lottery design and proportion of blanks, but that variation is not sufficient to identify $\lambda$.

I then fixed $\lambda=1.5$, near the median of my estimates, and estimated the other two parameters, cutting down drastically on computation time, and allowing me to start sensitivity analysis by changing $\sigma$ from 0.15 to 0.10 . 


\begin{tabular}{|c|c|c|c|c|c|c|c|}
\hline & \multicolumn{3}{|c|}{$\lambda$ free } & \multicolumn{4}{|c|}{$\lambda=1.5$} \\
\hline & \multicolumn{3}{|c|}{$\sigma=.15$} & \multicolumn{2}{|c|}{$\sigma=.15$} & \multicolumn{2}{|c|}{$\sigma=.10$} \\
\hline & $\gamma$ & $\lambda$ & $\alpha$ & $\gamma$ & $\alpha$ & $\gamma$ & $\alpha$ \\
\hline $\mathrm{N}$ & \multicolumn{3}{|c|}{14} & \multicolumn{2}{|c|}{26} & \multicolumn{2}{|c|}{26} \\
\hline $\min$ & 0.606 & 1.324 & 0.515 & 0.632 & 0.598 & 0.632 & 0.652 \\
\hline $\max$ & 0.817 & 2.010 & 0.988 & 0.913 & 1.111 & 0.842 & 1.044 \\
\hline median & 0.706 & 1.660 & 0.920 & 0.729 & 0.930 & 0.737 & 0.932 \\
\hline mean & 0.703 & 1.643 & 0.851 & 0.731 & 0.892 & 0.731 & 0.899 \\
\hline IQR & 0.041 & 0.171 & 0.124 & 0.066 & 0.148 & 0.081 & 0.084 \\
\hline std dev & 0.057 & 0.190 & 0.156 & 0.060 & 0.121 & 0.054 & 0.115 \\
\hline
\end{tabular}

Table 17: Summary statistics of the preference parameters estimated on the various lotteries.

The summary statistics of the estimates are presented in Table 17. The estimates are plotted in Figures 5. As said, when $\lambda$ is left tree estimates vary considerably, and I cannot find a minimum within the admissible range of parameters $(\lambda \geq 1, \alpha<1, \gamma<1)$. When $\lambda$ is fixed at 1.5 the estimates of $\gamma$ and $\alpha$ are not very different, which confirms that $\lambda$ is poorly identified in the data. With two exceptions (the 1711 and 1723 lottery) the parameter estimates are within the theoretical bounds $(0,1)$, closely clustered and not at all sensitive to the calibration of $\sigma$, the volatility of the Gaussian asset. The $\alpha$ parameter (curvature of the gain and loss function) ranges between 0.6 and 1.1 and mostly clusters close to 0.92 . The $\gamma$ parameter estimates are more tightly clustered and suggest a significant distortion of probabilities.

How well do the parameter estimates account for the time path of lottery prices over the course of each draw? The answer, shown in Figure 6: not really. The failure, however, is interesting: the model captures the average level of lottery prices, but cannot explain the pattern of prices rising over the course of the draw. The median autocorrelation of prediction errors is 0.94 . Figure 7 shows the correlation between predicted and actual prices for the different lotteries. It's mostly positive, and for some years quite high, but clearly the model does not capture variations in market prices equally well across lotteries.

Reproducing the level of the lotteries' prices is still appreciable progress. Figure $8 \mathrm{com}-$ pares actual prices, expected values (i.e., risk-neutral pricing), and the prices predicted by the CPT model with the median estimates of the parameter values.

\section{Conclusion}

This paper is about substantial pricing anomalies. The British government used lottery loans extensively over several decades, and was able to sell these randomized bonds at a hefty premium over the non-random version of the bond. Information about the lotteries was complete, and investors were serious people: prosperous merchants putting substantial amounts of money at stake, the leading men of the leading economy, those who made possible the Industrial Revolution.

Some evidence (the existence of lottery insurance, the fact that the government repeatedly varied the design of the lotteries) suggests that investors cared about certain aspects of the prize distribution, not just skewness in general. 

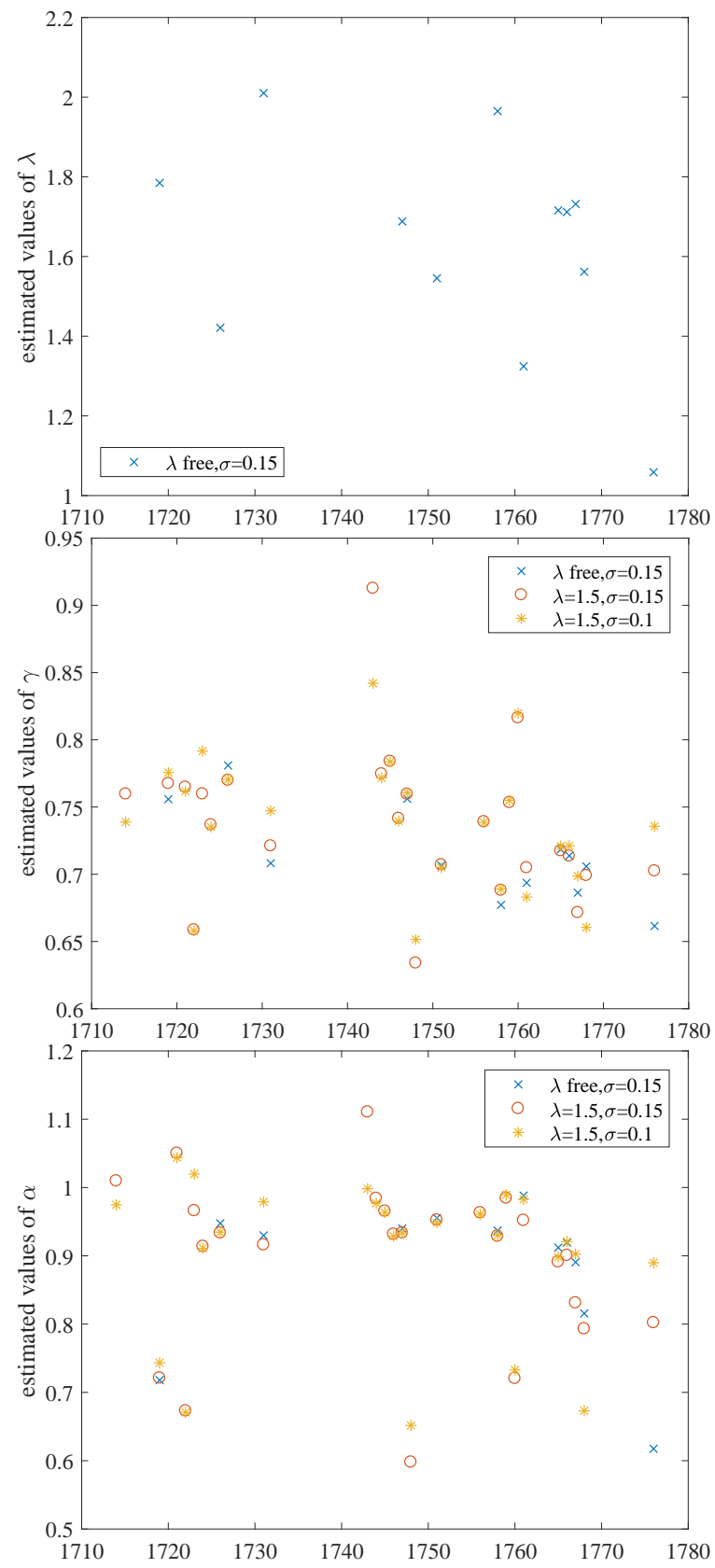

Figure 5: Estimates of the preference parameters across the different lotteries. 


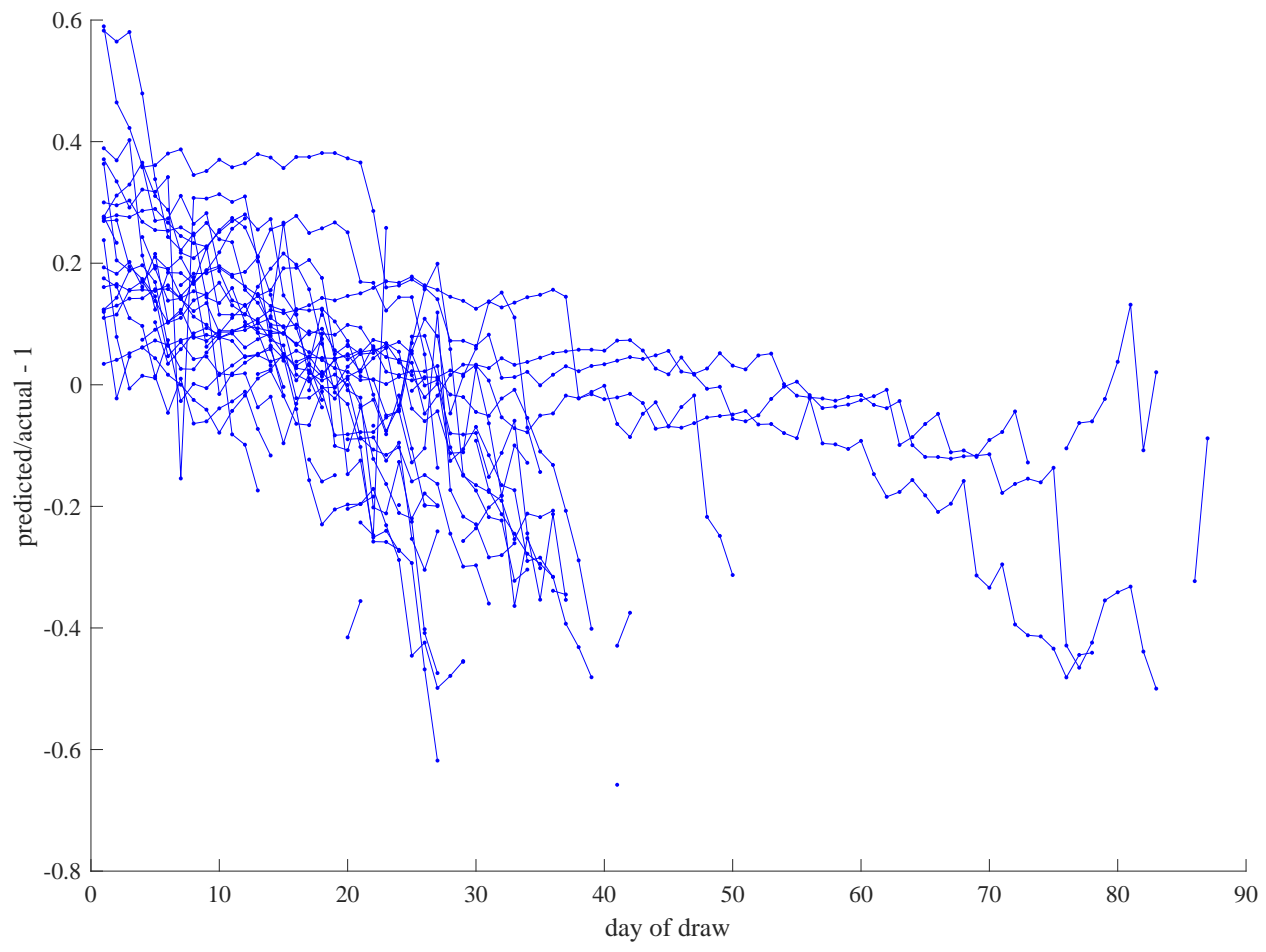

Figure 6: Predicted and actual lottery prices over the course of the draw.

The equilibrium model of Barberis and Huang (2008) can be estimated on these data. The model can account for the lottery premium, but seems so far unable to capture the bubble-like rise in prices over the course of the draws. 


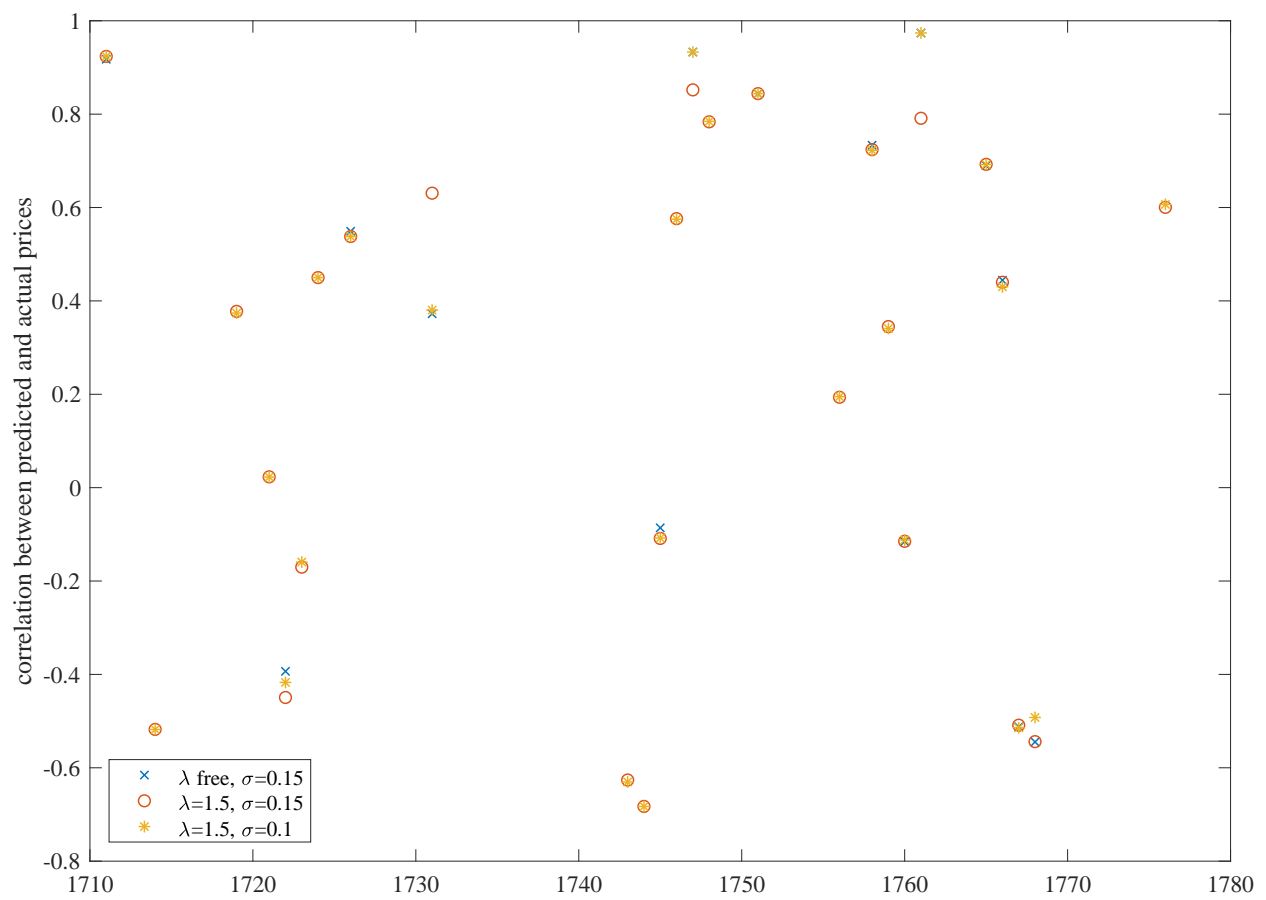

Figure 7: Correlation between predicted and actual lottery prices over the course of the draw.

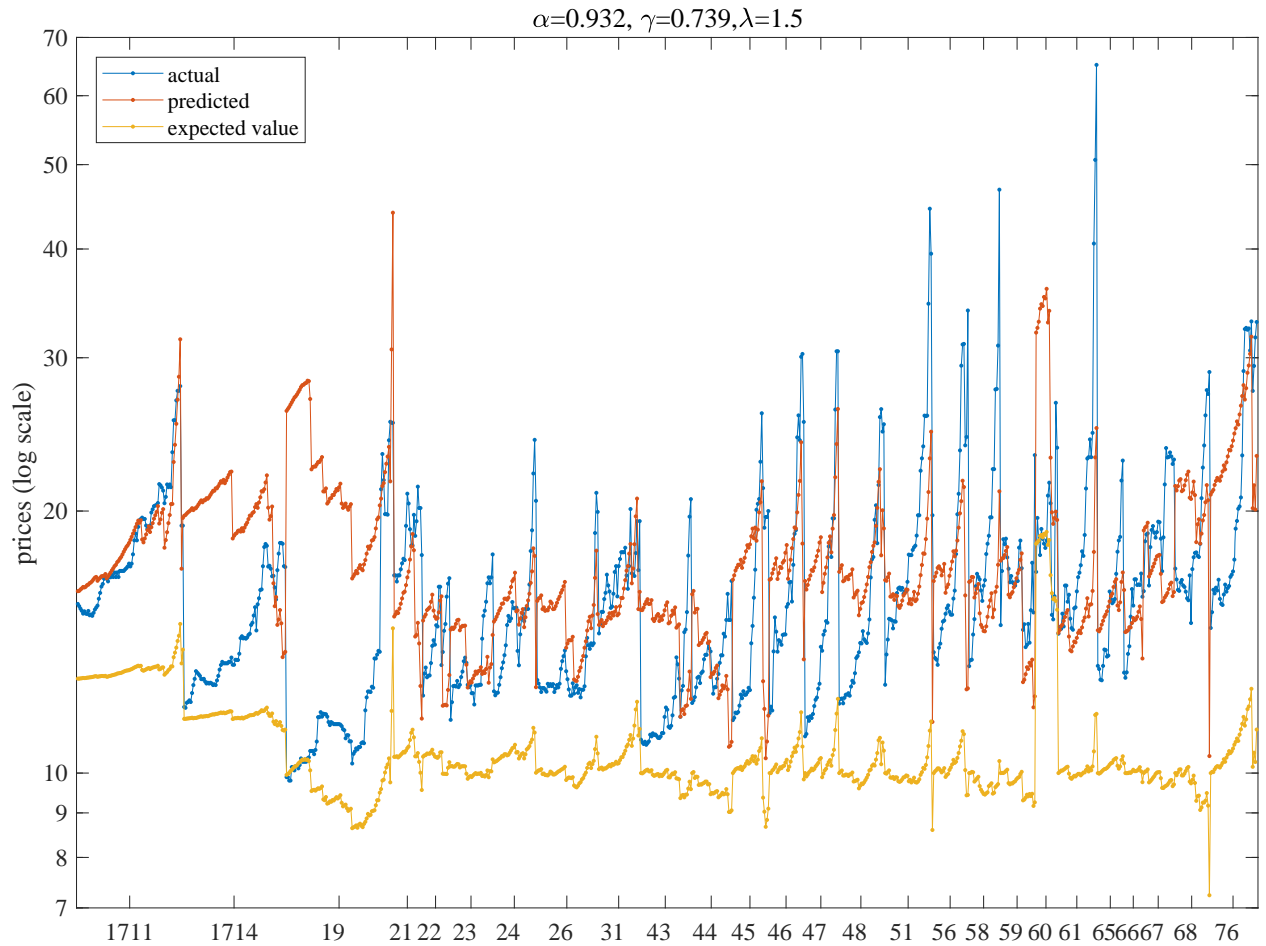

Figure 8: Actual lottery prices, expected values, and predicted prices with fixed parameters. 


\section{Appendix: Calculation of Equilibrium}

Suppose a lottery has prizes $\left\{L_{i}\right\}_{i=1}^{N}$ with probabilities $\left\{q_{i}\right\}_{i=1}^{N}$. The value function of an investor who has put a share $x$ of his portfolio in the lottery at price $p$ is

$$
V(x, p)=-\int_{-\infty}^{0} v(R) d w(P(R))+\int_{0}^{+\infty} v(R) d w(1-P(R))
$$

where

$$
w(P)=\frac{P^{\gamma}}{\left(P^{\gamma}+(1-P)^{\gamma}\right)^{1 / \gamma}}
$$

is the function distorting probabilities,

$$
v(R)= \begin{cases}R^{\alpha} & \text { if } R \geq 0, \\ -\lambda(-R)^{\alpha} & \text { if } R<0\end{cases}
$$

is the value function, and $P(R)$ is the cumulative distribution function of the return $R$ on the portfolio. Since I assume that the return on the market portfolio is normally distributed with mean $\mu$ and variance $\sigma$,

$$
P(R)=\sum_{i=1}^{N} q_{i} N\left(\frac{1}{\sigma}\left(R-x\left(\frac{L_{i}}{p}-R_{f}\right)-\mu\right)\right) .
$$

where $N(x)$ is the c.d.f. of a $N(0,1)$ random variable. The goal function $V(x, p)$ is therefore a sum of integrals:

$$
\begin{aligned}
V(x, p)=\sum_{i=1}^{N} \frac{q_{i}}{\sqrt{2 \pi} \sigma}\{ & -\int_{-\infty}^{0}-\lambda(-R)^{\alpha} w^{\prime}(P(R)) e^{-\frac{1}{2}\left(\frac{R-R_{i}}{\sigma}\right)^{2}} d R \\
& \left.+\int_{0}^{+\infty} R^{\alpha} w^{\prime}(P(R)) e^{-\left(\frac{R-R_{i}}{\sigma}\right)^{2}} d R\right\}
\end{aligned}
$$

with $R_{i}=x\left(\frac{L_{i}}{p}-R_{f}\right)+\mu$ and

$$
P(R)=\frac{1}{2}\left(1-\operatorname{sign}(R) \sum_{j=1}^{N} \operatorname{erf}\left[\frac{R-R_{j}}{\sqrt{2} \sigma}\right]\right)
$$

where $\operatorname{erf}[x]=\frac{2}{\sqrt{\pi}} \int_{0}^{x} e^{-t^{2}} d t$ is the error function.

The integrals in (6) are of the form $\int_{0}^{+\infty} f(x) x^{\alpha} e^{-x} d x$ for some suitably defined $f(x)$, or $\int_{-\infty}^{+\infty} g(X) e^{-X^{2}} d X$ for some suitably defined $g(X)$ and a change of variable $x=\sqrt{2} \sigma X+$ $R_{i}$; therefore they can be numerically computed using either Gauss-Laguerre or GaussHermite quadrature. Likewise the derivatives $\partial V(x, p) / \partial x$ and $\partial V(x, p) / \partial p$ can be computed analytically in terms of integrals that lend themselves to quadrature. 


\section{Bibliography}

Abdellaoui, Mohammed, Han Bleichrodt, and Olivier L'Haridon. 2008. "A tractable method to measure utility and loss aversion under prospect theory." Journal of Risk and Uncertainty 36, no. 3 (June): 245-266.

An Account Shewing the Numbers of the Tickets Entituled to Benefits in the Lottery for 1,400,000 L. 1715. London: R. Vincent.

An Account Shewing in Numerical Order the Tickets Entituled to Benefits in Each of the Lotteries, Anno 1719. 1719. London: Andrew / William Bell.

Allais, Maurice. 1953. “Le Comportement de l'Homme Rationnel devant le Risque: Critique des Postulats et Axiomes de l'Ecole Americaine." Econometrica 21, no. 4 (October): 503-46.

Ashton, John. 1893. A History of English Lotteries Now for the First Time Written. Leadenhall Press, Ltd.

Assereto, Giovanni. 2013. Un giuoco così utile ai pubblici introiti : Il lotto di Genova dal XVI al XVIII secolo. Roma: Viella Editore.

Barberis, Nicholas C. 2013. "Thirty Years of Prospect Theory in Economics: A Review and Assessment." Journal of Economic Perspectives 27 (Winter): 173â€"-96.

Barberis, Nicholas, and Ming Huang. 2008. "Stocks as Lotteries: The Implications of Probability Weighting for Security Prices." American Economic Review 98 (5): 2066-2100.

Bellhouse, D. R. 1991. “The Genoese Lottery.” Statistical Science 6 (2): 141-148.

Bernard, Bruno, Claude Bruneel, Helma Houtman-De Smedt, Michel Maffesoli, Robert Muchembled, and Romain Van Eenoo, eds. 1994. Loteries en Europe, cinq siècles d'histoire. Brussels: Loterie Nationale.

Boyer, Brian H., and Keith Vorkink. 2014. "Stock Options as Lotteries." The Journal of Finance 69 (4): 1485-1527.

Brunnermeier, Markus K., and Jonathan A. Parker. 2005. “Optimal Expectations.” American Economic Review 95, no. 4 (September): 1092-18.

Carruthers, Bruce G. 1996. City of Capital: Politics and Markets in the English Financial Revolution. Princeton, NJ: Princeton University Press.

Cobbett, William. 1806-1820. The Parliamentary History of England from the Earliest Period to the Year 1803. T. C. Hansard.

Cohen, Jacob. 1953. "The Element of Lottery in British Government Bonds, 1694-1919." Economica, New Series, 20, no. 79 (August): 237-46.

Conrad, Jennifer, Robert F. Dittmar, and Eric Ghysels. 2013. “Ex Ante Skewness and Expected Stock Returns." The Journal of Finance 68 (1): 85-124. 
Crossley, Thomas F., Hamish Low, and Sarah Smith. 2011. Do consumers gamble to convexify? Working paper 11,07 . IFS.

Dickson, Peter George Muir. 1967. The Financial Revolution in England : a Study in the Development of Public Credit, 1688-1756. London: Macmillan.

Doran, John. 1880. Annals of the English Stage. New York: A. C. Armstrong / Son.

Douen, Orentin. 1894. La Révocation de l'Édit de Nantes à Paris d'apès des documents inédits. Paris: Librairie Fischbacher.

Eraker, Bjørn, and Mark Ready. 2013. Do Investors Overpay for Stocks with Lottery-like Payoffs? An Examination of the Returns of OTC Stocks. Technical report. Wisconsin School of Business, Department of Finance.

Etchart-Vincent, Nathalie. 2009. "Probability weighting and the 'level' and 'spacing' of outcomes: An experimental study over losses." Journal of Risk and Uncertainty 39, no. 1 (August): 45-63.

Ewen, Cecil L'Estrange. 1932. Lotteries and sweepstakes; an historical, legal, and ethical survey of their introduction, suppression and re-establishment in the British isles. London: Heath, Cranton.

Florentsen, B., and K. Rydqvist. 2002. “Ex-Day Behavior When Investors and Professional Traders Assume Reverse Roles: The Case of Danish Lottery Bonds." Journal of Financial Intermediation 11, no. 2 (April): 152-75.

Fokker, Gerrit Adriaan. 1862. Geschiedenis der loterijen in de Nederlanden. Amsterdam: Frederik Muller.

Gallais-Hammono, Georges, and Christian Rietsch. 2013. “Learning by Doing: the Failure of the 1697 Malt Lottery-Loan." Financial History Review 20 (August): forthcoming.

Garrett, Thomas A, and Russell S Sobel. 1999. “Gamblers favor skewness, not risk: Further evidence from United States' lottery games." Economics Letters 63 (1): 85-90.

Gilson, Matthieu, Kim Oosterlinck, and Andrey D. Ukhov. 2013. "Risk Aversion during World War II: Evidence from Belgian Lottery Bond Prices."

Goldstein, William M., and Hillel J. Einhorn. 1987. “Expression Theory and the Preference Reversal Phenomena." Psychological Review 94 (2): 236-54.

Golec, Joseph, and Maurry Tamarkin. 1998. “Bettors Love Skewness, Not Risk, at the Horse Track." Journal of Political Economy 106 (1): 205-225.

Goodwyn, Henry William. 1876. The Goodwyns of Lynn Regis, Norfolk. Lymington: Edward King.

Green, Clifton, and Byoung-Hyoun Hwang. 2012. "Initial Public Offerings as Lotteries: Skewness Preference and First-Day Returns." Management Science 58 (2): 432-44. 
Green, Richard C., and Kristian Rydqvist. 1997. "The Valuation of Non-Systematic Risks and the Pricing of Swedish Lottery Bonds." Review of Financial Studies 10 (2): 447-80.

Guillén, Mauro F., and Adrian E. Tschoegl. 2002. “Banking on Gambling: Banks and LotteryLinked Deposit Accounts." Journal of Financial Services Research 21 (3): 219-31.

Hoekstra, Matthijs. 2010. "Necessity is the mother of invention: The lottery loans of Holland during the War of the Spanish Succession." Master's thesis, University of Utrecht.

Huisman, Anneke, and Johan Koppenol. 1991. Daer compt de Lotery met trommels en trompetten! : loterijen in de Nederlanden tot 1726. Hilversum: Verloren.

Kruckeberg, Robert D. 2009. “The Wheel of Fortune In Eighteenth-Century France: The Lottery, Consumption, And Politics." PhD diss., University of Michigan.

Lart, Charles Edmund. 1924. Huguenot Pedigrees. London: The saint Catherine press.

Lévy-Ullmann, Henri. 1896. "Lottery Bonds in France and in the Principal Countries of Europe." Harvard Law Review 9, no. 6 (January): 386-405.

Lindert, Peter H, and Jeffrey G Williamson. 1982. “Revising England's social tables 16881812." Explorations in Economic History 19, no. 4 (October): 385-408.

Lobe, Sebastian, and Alexander Hölzl. 2007. Why are British Premium Bonds so Successful? The Effect of Saving With a Thrill. Technical report.

Luttrell, Narcissus. 1857. A brief Historical Relation of State Affairs: from September 1678 to April 1714. Oxford: Oxford University Press.

Millar, James R., and James A. Gentry. 1980. “The Soviet Experiment with Domestic Lottery Bonds." Financial Management 9 (Winter): 21-29.

Murphy, Anne. 2005. "Lotteries in the 1690s: investment or gamble?" Financial History Review 12 (2): 227-46.

Pepys, Samuel. 1894. Diary. London: George Bell / Sons.

Pfiffelmann, Marie. 2012. “Le Mariage efficace de l'épargne et du jeu : une approche historique." Revue d'économie politique 121 (6): 893-914.

Rhodes, Cecil. 1711a. An Account Shewing the Numbers of the Tickets Entituled to Benefits in the Lottery for 1500,000 L. Anno 1711. London: Andrew Bell.

-1711b. An Exact Table or List of all the Numbers of the Tickets or Receipts Drawn in the Two Million Adventure. London: Andrew Bell.

Richards, R. D. 1934. "The Lottery in the History of English Government Finance." Economic History 3, no. 9 (January): 57-76.

Ridge, Jenny, and Martin Young. 1998. “Innovations in savings schemes: The bonus bonds trust in New Zealand." Financial Services Review 7 (2): 73-81. 
Rieger, Marc Oliver, Mei Wang, and Thorsten Hens. 2017. “Estimating Cumulative Prospect Theory Parameters From an International Survey." Theory and Decision 82 (April): $567 \hat{a} €^{\prime \prime}-96$.

Roger, Patrick. 2011. “Testing Alternative Theories of Financial Decision Making: A Survey Study With Lottery Bonds." Journal of Behavioral Finance 12 (4): 219-32.

Roussanov, Nikolai. 2010. "Diversification and Its Discontents: Idiosyncratic and Entrepreneurial Risk in the Quest for Social Status." Journal of Finance 65, no. 5 (October): 1755-88.

Thijs, Alfons K. L. 1994. "Les loteries dans les Pays-Bas méridionaux (XVe-XVIIe siècle)." In Geschiedenis van de Ioterijen in den zuidelijke Nederlanden (15de eeuw-1934), edited by Ilsa Eggers. Brussels: Algemeen Rijksarchief.

Tufano, Peter. 2008. "Saving Whilst Gambling: An Empirical Analysis of U.K. Premium Bonds." American Economic Review Papers and Proceedings 98, no. 2 (May): 321-26.

Tversky, Amos, and Daniel Kahneman. 1992. "Advances in Prospect Theory: Cumulative Representation of Uncertainty." Journal of Risk and Uncertainty 5 (4): 297-323.

Ukhov, Andrey D. 2010. "Preferences Toward Risk and Asset Prices: Evidence from Russian Lottery Bonds."

United Kingdom. 1898. History of the Earlier Years of the Funded Debt, from 1694 to 1786. LII:269-348. Command Papers C. 9010. HM Stationery Office.

Walford, Cornelius. 1885. "Lotteries: the Part they have Played in State Finance." Journal of the Institute of Bankers 6, no. 2 (February): 71-94.

Welch, Evelyn. 2008. “Lotteries in Early Modern Italy." Past E Present 199, no. 1 (May): 71-111. 